\title{
29 Moving towards Perfection: Physical Culture in Dzogchen as Revealed in Tibet's Lukhang Murals
}

Ian A. Baker

A set of murals created in Lhasa at the end of the 17th century reveal mind-body practices within Tibetan Buddhism that have traditionally been kept hidden from non-initiates, in part because of the practices' perceived threat to monastic and clerical conventions. The bodybased disciplines depicted on the walls of what was once a private meditation chamber for Tibet's Sixth Dalai Lama are part of the Dzogchen (rdzogs chen), or 'Great Perfection' teachings that developed within Tibet's earliest transmission of tantric Buddhism. Commissioned by Tibet's then ruling political regent Desi Sangye Gyatso (Sde srid sangs rgyas rgya mtsho) (1653-1705), the Lukhang murals' artistic virtuosity reflects intellectual, doctrinal, and political concerns during one of Tibet's greatest periods of cultural production and innovation.

This chapter explores the diverse motivations that informed the creation of the Lukhang murals, but focuses more specifically on the murals' enduring didactic content: the means by which the human body can be cultivated, according to the 'Great Perfection' teachings of the Nyingma, or 'ancient' order of Tibetan Buddhism, as an agency of release from suffering and discontent, culminating in realisation of the mind and body's inherent 'Buddha Nature' (de gshegs snying po, Skt: tathāgatagarbha).

\section{The Yoga of Non-Duality}

The 'Great Perfection' or Dzogchen teachings of Tibet are upheld as revealing the ultimate unconditioned nature of human consciousness without recourse to the theological rites and practices that characterise the tantric, or Vajrayāna, form of Buddhism from which Dzogchen arose. ${ }^{1}$ Described as both the essence and culmination of

1 Dzogchen, is also known as Ati, or 'utmost' Yoga (shin tu rnal 'byor), and is presented in Nyingma tradition as the culmination of nine processual vehicles for actualising enlightenment - union with all-encompassing awareness transcendent of all afflictive fluctuations of consciousness. The first two vehicles refer to the Hīnayāna stages of Śrāvakayāna and Pratyekayāna that lead to the solitary realisation of the arhat, as represented today by Theravāda Buddhism. The third vehicle, Bodhisattvay $\bar{a}-$ $n a$, introduces the Mahāyāna or greater vehicle, and cultivates enlightenment not just for oneself, but for all beings. The fourth, fifth, and sixth vehicles are the so-called Outer Tantras of Kriyātantra, Caryātantra, and Yogatantra, all of which are part of the Vajrayāna ${ }^{2}$ Buddhist path to 'pure and total presence' (byang chub kyi sems), Dzogchen is held to liberate consciousness from latent discontent through ever-present awareness (rig pa) of the ultimately non-dual (gnyis med) nature of mental experience. As explicated in the 'Six Vajra Verses' (Rig pa'i khu byug), one of Dzogchen's earliest known literary sources:

Recognising that everything is self-perfected from the very beginning and beyond the constraints of conceptualising mind, the malady of striving is spontaneously relinquished. One remains immaculately at ease in innate perfection. ${ }^{3}$

the Vajrayāna, or third turning of the wheel of doctrine, but are still dualistic in their orientation. The three Inner Tantras were transmitted to those deemed of higher capacity and consist of Mahā Yoga, which emphasises the development stage (bskyed rim) of creative perception, Anu Yoga, which cultivates co-emergent bliss and emptiness through completion stage (rdzogs rim) practices based on an imaginal body of channels, winds and essences, and Ati Yoga, the resultant non-duality of Dzogchen with its liberating praxis of primordial, self-existing perfection. The three Inner Tantras of the Nyingma further correlate with the Unsurpassed Yoga Tantras (Anuttarayogatantra) of the Kagyu, Sakya, and Geluk lineages, all of which culminate in the non-dual (Advaitayoga) view of reality as expressed in Essence Mahāmudra (ngo bo'i phyag rgya chen po) which is identical, in outlook, to Dzogchen, the 'Great Perfection', but differs in method and presentation.

2 Founded by Indian mahāsiddha, or realised adepts, Vajrayāna, is a multifaceted and complex system of Buddhist thought and practice, which evolved over many centuries. Also known as Tantric Buddhism, Tantrayāna, Mantrayāna, Secret Mantra, Esoteric Buddhism and the Diamond Way or Thunderbolt Way, Vajrayāna, refers to one of three Buddhist vehicles or routes to enlightenment, the other two being Theravāda and Mahāyāna. For discussion of the phases of introduction of Vajrayāna Buddhism to Tibet, see Kapstein 20oo; Snellgrove 1987.

3 Also known as 'The Cuckoo's Song of Total Presence', this seminal text is considered the basis of Dzogchen practices emphasising the nature of consciousness (sems sde). A version of this text was discovered among materials sealed into a chamber at the oasis of Dunhuang in the 1oth century, but the text is held by tradition to date originally to the 8th century when Tibet's first Dzogchen master, Vairocana, allegedly received it from Śrī Siṃha in the legendary land of Uḍḍiyāna. 


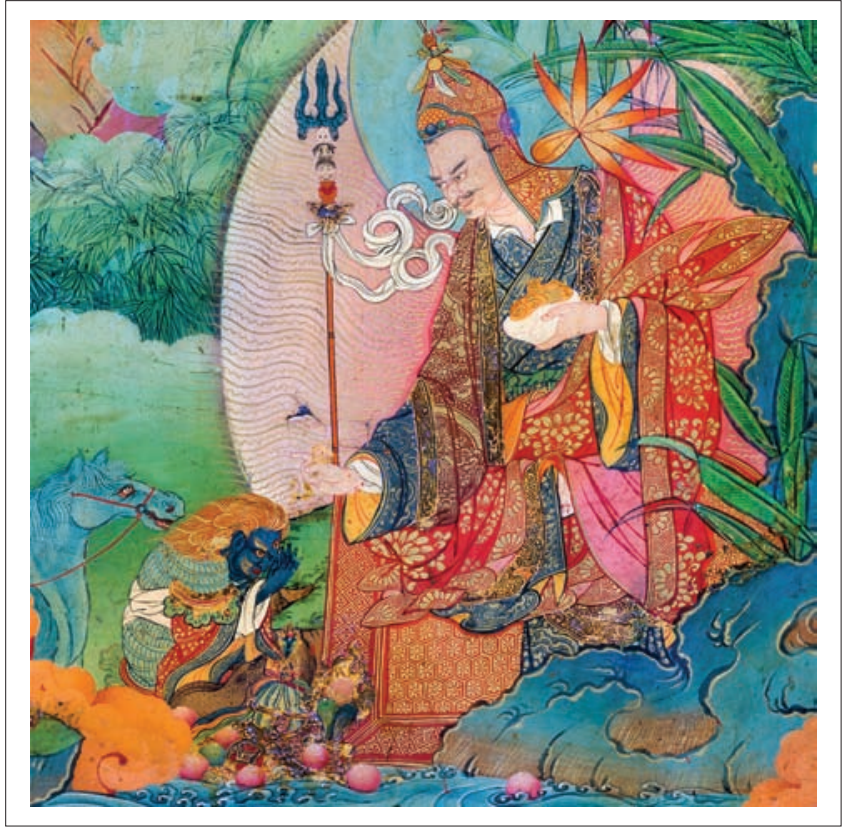

Figure 29.1 Padmasambhava accepting obeisance from an elemental nature spirit called a Lu (Skt: naga), as shown on a mural in Tibet's Lukhang Temple. ${ }^{\odot}$ Ian Baker

Similarly, Padmasambhava, ${ }^{4}$ the 8 th-century figure most commonly identified as having established the Dzogchen teachings in Tibet, reputedly proclaimed that:

In its true state the mind is naked, immaculate, clear, without duality, transparent, empty, timeless, uncreated, unimpeded; not realisable as a separate entity, but as the unity of all things... . To know whether or not this is true, look into the nature of your own mind. ${ }^{5}$

Padmasambhava, the 'Lotus Born', is a quasi-supernatural personality in Tibetan Buddhist hagiography, who is credited with eight archetypal manifestations and innumerable emanations. He is said to have originated in Uḍdiyāna, a region known for its syncretic traditions, currently encompassing parts of northern Pakistan, Afghanistan, and Kashmir. Asked who he was, he allegedly replied; 'My father is wisdom. My mother is selflessness. My country is Reality, just as it is. I take thoughts as food and have come here to destroy sorrow'. There are clear parallels between the Dzogchen tradition attributed to Padmasambhava and non-dual Kashmiri Śaivism that includes the practice of 'Sambhava Yoga', referring to the radiance of intrinsic consciousness when freed from all ideation. Similarly, Uḍ̣iyāna, from where Padmasambhava is said to have originated, refers to a specific hațha yoga practice, Uḍdiyāna, or 'flying upward', $m u d r a \bar{a}$, used for directing energy and awareness into the body's central meridian (rtsa dbuma). For evidence of the influence of Kashmiri Śaivism on the development of Vajrayāna Buddhism, see Alexis Sanderson's extensive publications in the field (www. alexissanderson.com). To compare relevant passages of the śaiva āgama with Dzogchen pith instructions (man ngag), see Singh 1979; Odier 2005.

$5 \quad$ Evans-Wentz (ed.) 1954, p. 183.
While Dzogchen is commonly perceived, and presented, as pertaining to the innate 'self-liberating' potential of human consciousness and thus considered superior to transformation-based tantric disciplines, its practice is traditionally infused by physical exercises that push the body - and thereby the mind - beyond conventional limits and constraints. These disciplines range from physically and imaginatively demanding 'preliminary practices' (sngon 'gro) to supportive Qigong and hațha-yoga-related exercises (rtsa rlung 'khrul 'khor) ${ }^{6}$ that amplify innate somatic processes preparatory to Dzogchen's more widely known and transmitted contemplative techniques of 'cutting through' (khregs chod) and 'leaping over' (thod rgal), the latter involving precise body postures, breathing techniques, and visual focus. Auxiliary Dzogchen practices involve condensed renditions of the so-called Six Yogas, ${ }^{7}$ geared towards recognising the Natural State (gnas lugs) of non-dual awareness (gnyis med) at all stages of waking, dreaming, sleeping, and posited post-mortem states of consciousness. In all aspects of Dzogchen practice, the body is cultivated and its natural processes enhanced and ultimately transcended, in order to facilitate effortless abiding in the self-liberated radiance of intrinsic awareness, equated in Dzogchen with the 'Buddha Nature' (bde bar gshegs pa'i snying po, Skt: sugatagarbha) held to be latently present within all beings. As stated in the Secret Nucleus:

6 rtsa rlung breathing practices that alter the flow of somatic energy are typically enhanced by the dynamic yogic movements of 'khrul 'khor to both improve health and expand the body's capacity for inner experience. Geoffrey Samuel has pointed out that the Tibetan Buddhist Resource Center (TBRC) alone includes 26o 'khrul 'khor-related texts, although little research has been devoted to the subject. He further notes that some of these texts are included in the Tengyur and thus held to be translations of original Indian texts.

$7 \quad$ Associated with the 11th-century Indian mahāsiddha Nāropā (956-1041), the 'Six Yogas' ( a ro chos drug) derive from the 'Yoginī Tantras' of Anuttarayogatantra and refer in reality to a larger and shifting set of processual yogic practices directed towards awakening habitually dormant human capacities during the recurring phases of waking, dreaming, and sleeping as well as at the time of death and its aftermath. The inclusion of the Six Yogas in 'rediscovered' Dzogchen treasure texts (gter ma) suggests the influence on the Nyingma tradition of teachings brought from India to Tibet by Marpa Lotsawa in the 11th century and propagated within the Kagyu lineage of 'whispered secrets'. For an overview of the Six Yogas and their diffusion in Tibet in connection with the development of the Kagyu, Sakya, and Geluk orders, see Mullin 20o6; Dudjom Rinpoche 1991, pp. 284-9; Kongtrol 2005, pp. 330-7. 
The Perfect Buddha is not found in any of the 10 directions or four times. Other than the perfect Buddha which is mind-as-such, do not seek the Buddha elsewhere. ${ }^{8}$

As Dzogchen treatises repeatedly point out, the human body is an unsurpassable vehicle for the realisation of the radiant and selfless expanse of enlightened awareness that dualistic subject-object mentation habitually obscures. ${ }^{9}$

Dzogchen teachings in Tibet were traditionally closely guarded as their uncompromising and doctrinally challenging elucidations of the nature of mind were often perceived as being in conflict with monastic traditions based on ceremonial magic and scriptural study. Dzogchen methods for awakening to the posited innate mind of enlightenment were transmitted primarily through Tibet's Nyingma, or 'Ancient' order, which traces its origins to the 8th-century Buddhist masters Padmasambhava and Vairocana, who are credited with having brought the teachings of 'Great Perfection' from Uḍ̣iyāna, a legendary realm at the northwest frontiers of the Indian sub-continent. The Dzogchen, or Ati Yoga, lineage is held to have spread beyond Uḍdiyāna with the 'Three Incisive Precepts' (Tshig gsum gnad brdegs) transmitted by the quasi-historical Prahevajra (Tib: Dga' rab rdo rje) to his Brahman disciple, Mañjuśrīmitra ('Jam dpal bshes gnyen). ${ }^{10}$ Dzogchen evolved in Tibet and neighbouring Himalayan countries from the 8th century onward and, beginning in the 11th century, through a tradition of rediscovered 'treasure texts' $(\text { gter } m a)^{11}$ revealed

8 Guhyagarbha Tantra, Tib: Rgyud gsang ba'i snying po. This Tantra predates the appearance in Tibet of specifically Dzogchen works and is upheld in Nyingma tradition as authenticating Dzogchen's deconstructionist presentation of experiential reality. The 'Reverberation of Sound' (Sgra thal 'gyur), the root tantra for the 17 Dzogchen Tantras of the secret instruction series, states that 'the union of body and mind connects primordial space with pristine awareness ... realising that, all beings are naturally buddhas!'

10 Prahevajra's final testament summarises Dzogchen's existential view, meditative practice, and ubiquitous application. These are encapsulated in outer, inner, and secret precepts: recognising the nature of mind (sems sde), remaining in non-dual 'spaciousness' (klong sde), and applying that realisation in all circumstances (man ngag). These three aspects of Dzogchen are further associated with the interrelated experiences of clarity, open presence, and the unity of emptiness and appearance.

11 Revealed treasure texts (gter $m a$ ) are invariably attributed to Padmasambhava and typically consist of meditative instructions (khrid), empowerments (dbang), and root tantras (rgyud), with miscellaneous ritual treatises often appended at the end. They can vary in length from a single text to more than a hundred. Treasure texts reinforce tradition by attributing literary and conceptual innovation to the founding figure of Padmasambhava while including new and sophisticated techniques of yo- by Padmasambhava's lineal successors. While faithful to Dzogchen's original ethos of the primordial purity $(k a$ dag) of selfless unitary consciousness and non-reliance on external rites, the Dzogchen treasure texts nonetheless increasingly incorporated hațha-yoga-like techniques that were perceived as supportive and complementary to Dzogchen's core contemplative practices by which the physical body could ultimately be dematerialised into an immortal body of rainbow light ('ja'lus). ${ }^{12}$

gic practice that entered Tibet from the late 1oth century onward in a subsequent wave of transmission from Indian mahāsiddhas, or realised adepts. Devotees of Tibet's original Nyingma order maintain that comparable teachings had been transmitted centuries earlier by Padmasambhava to his primary Tibetan consort, Yeshe Tsogyal, who encoded them on 'yellow scrolls' (shog gser) and hid them in rock walls, temple pillars, and other locations to be discovered in future generations by designated 'treasure finders' or terton (gter ston). This practice allowed renewal of Nyingma doctrine to occur within the stability of orthodox tradition. But, as was the case throughout Tibet's history, the ambiguity of the texts' historical sources raised concerns of authenticity while the overtly creative and non-conventional lives of the tertons themselves allowed for the possibility, at least to their detractors, of their subverting the practice to support elaborate agendas of self-advancement. The lack of any traceable Indic source for the revealed treasure texts attributed to Padmasambhava continues to vex Tibetan Buddhist tradition. While certain schools of Tibetan Buddhism view texts such as Pema Lingpa's 'Compendium of Enlightened Spontaneity' (Rdzogs chen kun bzang dgongs' dus) as indisputable expressions of Padmasambhava's enlightened mind and, by extension, the essence of the transcendental Buddha Amitābha that Padmasambhava is held to embody, other schools view the texts with suspicion and at times with outright hostility. Matthew Kapstein describes this historical rift between the idealism of living revelation and a more critical historical orientation as having led, over time, to 'purely political considerations whose perverse alchemy transformed the gold of religious vision into the base metal of violent sectarianism' (Kapstein 2000, p. 135). As Kapstein points out, the great Tibetan scholar and tantric master Tāranātha (1575-1634) had articulated the possibility of a middle ground 'by affirming that while at least some of the treasures were genuinely based upon early materials, they were at the same time, nevertheless, elaborated by their "discoverers". In this formulation alone do we find the possibility of an alternative to the aporia of unimpeachable authenticity versus willful fraud'. (Kapstein 2000, p. 135). See also Kapstein 1989, pp. 217-44 and Gyatso 1993, pp. 97-210. For further discussion of the terma (gter ma) tradition, see Gyatso 1998, as well as Thondup 1986.

12 Tibet's pre-Buddhist Bon tradition also includes hațha-yoga-like practices but, rather than ascribing them an Indic source, maintains that they originated in Tibet through the lineage of the Shang Shung Nyengyud. For the Bon presentation of Dzogchen, see Namdak and Myrdhin Reynolds 2006; Namdak and Dixey 2002. 


\section{The Lukhang Murals}

In the $15^{\text {th }}$ century, the Nyingma treasure master Terton Orgyen Pema Lingpa (Orgyan padma gling pa) (1450-1521) revealed a highly influential Dzogchen treasure text entitled 'Compendium of Enlightened Spontaneity' (Rdzogs chen kun bzang dgongs'dus) ${ }^{13}$ from a stūpa above Samye Monastery in Central Tibet. Ascribed to Padmasambhava, the treasure text emphasises Dzogchen pith instructions (man $n g a g$ ) for realising the exalted state of 'Great Perfection' through body-oriented techniques ranging from methods of hațha and kuṇdalini yoga ${ }^{14}$ to specific

'Great Perfection: Compendium of Enlightened Spontaneity' (Rdzogs chen kun bzang dgongs' dus) is one of three texts revealed by Pema Lingpa that elucidates the Great Perfection (rdzogs chen). Alternative translations of Rdzogs chen kun bzang dgongs' dus include Sarah Harding's 'Great Completion: Union of Samantabhadra's Intentions'. Kun bzang is a contraction of kun tu bzang po meaning 'All Good' or 'Ever Good', a name referring to the primordial Buddha and the principle of enlightenment. $d$ Gongs pa is often translated as 'intention', but as Buddha activity is spontaneous and unpremeditated, I prefer the alternative translation 'wisdom' which retains more of the spontaneity expressed in Pema Lingpa's presentation of the Dzogchen teachings. Although I have chosen to render Pema Lingpa's revealed text as 'Great Perfection: Compendium of Enlightened Spontaneity', it could also be 'Great Perfection: Compendium of Spontaneous Wisdom'. For a full inventory of Pema Lingpa's revealed treasures, see Harding 2003, pp. 142-4. A set of Pema Lingpa's original manuscripts is preserved at Gangteng (or Gangtey) Monastery in Bhutan. Reproductions were sponsored by Her Majesty the Royal Grandmother of Bhutan, edited by the great Nyingma master Dudjom Rinpoche, and published in 21 volumes by the National Library of Bhutan in Thimphu. Pema Lingpa's treasure corpus is also available as digital scans at Tibetan Buddhist Resource Center (www.tbrc.org) through the efforts of Gene Smith and the generous support of Chris Tomlinson. For more on the life and activities of Pema Lingpa, see Harding 2003; Aris 1988; Tshewang et al. 1995 .

14 Hatha, literally 'forceful', yoga was expounded in a 15th-century Sanskrit treatise by Svāmi Svātmārāma entitled Hațha Yoga Pradīpikā. Widely available in modern English translations, the text was previously considered to be one of the earliest presentations of hațha yoga, although recent research by Birch (2011), Mallinson (2014), Singleton (2015), and others has revealed far earlier textual origins. Like the two other well-known medieval classics of hațha yoga, Gheranda Samhitā and Siva Samhitā, the Hațha Yoga Pradīpikā offers a detailed overview of yogic postures (āsana) and breathing techniques (prānāayām) as well as the metaphysical anatomy of channels (nädi) and cakra and psychophysical energy of kuṇdalinī, or candāalī (Tib: gtum mo) that underlie both Hindu and Buddhist Tantra. Physical yogic practices in Tibet are generally held to have begun in the 11th century during the second diffusion of Vajrayāna, in particular body postures associated with Dzogchen's ultimate goal of allowing the body's psychophysical constituents to decompose into their intrinsic luminosity. Pema Lingpa's treasure text has had an enduring influence throughout the Himalayan world and elucidates the role of physical cultivation in teachings dedicated to attaining what Vajrayāna Buddhist tradition upholds as humankind's highest potential, the literal photonic enlightenment of mind and body.

In the late $17^{\text {th }}$ century, at what is often considered the height of Tibet's political consolidation and cultural efflorescence, ${ }^{15}$ the reincarnation of the Fifth Dalai Lama (Ngag dbang blo bzang rgya mtsho) (1617-82) was identified by Tibet's reigning chief minister as Rinchen Tsangyang Gyatso (Tshang dbyangs rgya mtsho) (1683-1705), a direct descendent of the Bhutanese Treasure Revealer Pema Lingpa, discoverer of the 'Compendium of Enlightened Spontaneity'. ${ }^{16}$ As Tibet's interregnum ruler, Desi Sangye Gyatso (Sde srid sangs rgyas rgya mtsho) (1653-1705) was furthermore a lineage-holder of the practices described in Pema Lingpa's treasure text, leading him to oversee the creation of a set of murals illustrating the contents of Pema Lingpa's revealed treatise on the walls of a meditation chamber intended exclusively for the Dalai Lamas and their closest preceptors and attendants. ${ }^{17}$ Representing

in association with the Kagyu order's transmission of 'whispered precepts'. The inclusion of hatha-yoga-like practices in a text ascribed to Padmasambhava supports the contention that the $\mathrm{Ny}$ ingma tradition of revealed treasures was, at least in part, a way of including in the Nyingma canon advanced tantric methods of internal transformation such as those described in the Six Yogas of Nāropā as well as the similarly formulated Six Yogas of Niguma that date from the same period and continue to be passed down within the Shangpa Kagyu sub-order. Like the Hața Yoga Pradīpikā, Pema Lingpa's 'treasure text' makes clear its intent to illuminate the essence of tantric methods that, within monastic settings, were often burdened with liturgical rites and coded language that concealed more than they revealed.

15 For details of events at this time, see Aris 1988; Baker 2011.

16 The Sixth Dalai Lama was a direct descendent of Pema Lingpa through his father, the Nyingma master Rigdzin Tashi Tendzin (Rig 'dzin Bkra shis bstan 'dzin) (1651-97), who hailed from the mountainous regions east of Bhutan and disseminated Pema Lingpa's lineage of non-celibate lay ordination to others of his Nyo clan, the progenitors of Bhutan's nobility and eventual royal family.

17 As Pema Lingpa's teachings spread within Tibet, 'Compendium of Enlightened Spontaneity' became central to the curriculum at Orgyen Mindroling, a prominent Nyingma monastery founded between 1670 and 1676 by Minling Terchen Gyurme Dorje (Smin gling gter chen gyur med rdo rje) (1646-1714), known also as Rigdzin Terdak Lingpa (Rig 'dzin gter bdag gling $p a$ ). Towards 
spiritual practices and insights beyond Tibet's monastic conventions, the murals continue to serve as visual guides to the psychophysical practices that infuse the Dzogchen tradition in which the human body is perceived and cultivated as a medium of spiritual illumination. ${ }^{18}$

The sequestered murals line the walls in the uppermost chamber of the Lukhang (klu khang), the 'Temple to the Serpent Spirits' situated on a willow-fringed lake beneath the southern escarpment of the Dalai Lamas' Potala Palace in Lhasa. ${ }^{19}$ Flowing across the walls within a surreal bluegreen landscape influenced by the painting styles of Qing dynasty China and Mughal India, the murals cover three sides of the room, as well as the corners, and illustrate

the end of the 17th century, Terdak Lingpa wrote an extensive commentary on Pema Lingpa's 'Compendium of Enlightened Spontaneity' entitled 'Total Illumination of the Essence: The Teaching Manual for the Union of Samantabhadra's Intentions' which continues to be used today at teaching centres associated with H.E. Gangteng Tulku Rinpoche, one of Pema Lingpa's three contemporary emanations. Summarising the contents of the Lukhang murals, the commentary begins with teachings on ngon dro (the common preliminary practices of Refuge, Bodhicitta, Vajrasattva, Mandala Offering, and Guru Yoga) followed by the $r d z o g$ chen extraordinary preliminaries (Inner, Outer, Secret, and Ultra Secret 'khor 'das ru shan, 'distinguishing samsāra and nirvāna'). The text then directly introduces intrinsic awareness (rig pa) and the associated practices of ka dag khreg chod, thod rgal, the four visions, arriving at direct experience, and transferring consciousness at the moment of death. Terdak Lingpa transmitted these teachings to Ngawang Lobsang Gyatso ( Ngag dbang blo bzang rgya mtsho), the Fifth Dalai Lama (1617-82) as well as to Rinchen Tsangyang Gyatso, the Sixth Dalai Lama (1683-1706/46), who, after his enthronement in 1697, rejected monastic ordination in favour of esoteric yogic practices such as those disclosed in Pema Lingpa's treasure text.

18 The link between Pema Lingpa's treasure text and the Lukhang murals was identified in 2002 by Jakob Winkler. See Winkler 2002, pp. 321-43.

19 Lukhang means 'Temple to the Serpent Spirits' and refers to its origins in a vision of the Fifth Dalai Lama during the construction of the Potala Palace. A serpent-like water deity called a $l u$ appeared to him during his meditations and warned that excavations behind the palace were disturbing the subterranean realm of the $l u$. In an act of reconciliation, the Fifth Dalai Lama vowed to build a temple to appease the lu once the Potala Palace was completed. This promise was fulfilled during the lifetime of the Sixth Dalai Lama (1683-1706) who made the resulting island temple his primary residence, in keeping with his controversial preference for romantic trysts and poetic composition over affairs of state. Over succeeding centuries the Lukhang continued to serve Tibet's Dalai Lamas as a place of spiritual inspiration and contemplative retreat. For details concerning the contents of the murals on the two lower floors of the Lukhang, see Luczantis 2011 . the principal contents of Pema Lingpa's treasure text 'Compendium of Enlightened Spontaneity'. 20

Apart from Padmasambhava's 25 Tibetan disciples who are shown grouped around the 8th-century Tibetan emperor Trisong Deutsen (Khri srong lde'u btsan), and images of Pema Lingpa, Pema Lingpa's previous incarnation Longchen Rabjampa (1308-64), and his descendant, Rigdzin Tashi Tendzin - father of the Sixth Dalai Lama - almost all other figures in the murals are shown as being of Indian origin. These include an entire mural depicting 42 of the 84 canonised Indian mahāsiddha (grub thob chen po), progenitors of Tibet's tantric lineages, as well as anonymous Dzogchen practitioners portrayed on the north and west walls, whose distinguishing hairstyles, skull bowls, and trident staffs connect them with the Kāpālika Śakta Saiva tantrism which shaped both the iconography and ritual practices of Vajrayāna Buddhism's most esoteric traditions. ${ }^{21}$

Although Pema Lingpa's treasure text directly associates the Dzogchen teachings with the practices of the $r s ̦ i$, or

20 According to the current Fourteenth Dalai Lama, the paintings that inscribe the private meditation chapel were executed under the combined direction of Desi Sangye Gyatso and Terdak Lingpa's younger brother, the accomplished artist Minling Lochen Dharma Shri (1654-1717). Prior to Desi Sangye Gyatso's production of the Lukhang murals, he masterminded the creation of a series of 79 scroll paintings depicting the Tibetan medical system as it was taught at Lhasa's Chakpori Medical College, which he founded in 1696. The artistic and didactic paintings were based on the Blue Beryl (Vaidūrya sngon po), the Desi's extensive commentary on the foundational Four Medical Tantras (Rgyud bzhi) that had been compiled in the 12th century and which continue to form the basis of Tibetan medical practice today. The medical paintings generated by the Desi, in collaboration with Tibet's top artists and physicians, continue to be reproduced throughout the world, although less now for instructional purposes than for their artistic merit and the insight they provide into Tibetan civilisation at its height of artistic and cultural production. See Gyatso 2012 for an overview of the various copies that have been produced of the 79 medical thangkas. Also see Parfionovitch, Dorje and Meyer 1992 and Baker 1997, the latter of which presents a late 2oth-century Nepalese rendition.

21 Vajrayāna's Yoginī tantras, in particular, draw on a corpus of Śaiva tantras classified as the Vidyāpitha, or 'locus of knowledge', of the Bhairava component of esoteric Kashmiri Śaivism. The Buddhist Yoginī tantras adapted pre-existing Śaiva texts while assimilating Śaiva deities, mantras, ritual procedures, mandalas, Kāpālika accoutrements, specialised terminology, and secret gestures into a system of yogic practice infused with the core Mahāyāna principles of benevolence, compassion, joy, and equanimity. Most tellingly, Pema Lingpa's revealed treasure text, as transcribed on the wall, begins with the words, 'Thus follow the teachings of the rși, the Vedic seers of ancient India. 


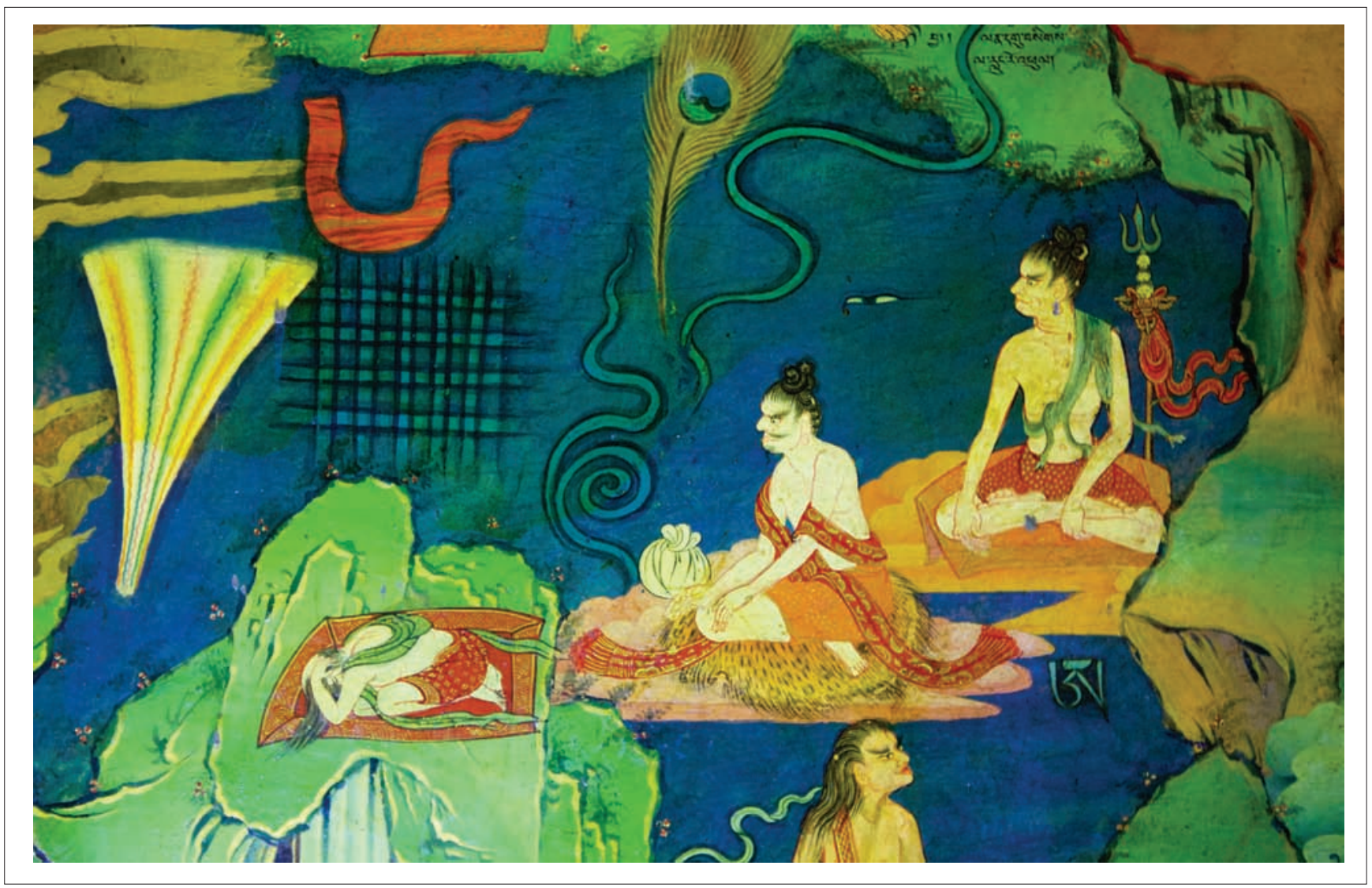

Figure 29.2 Practitioners of 'Great Perfection' (Dzogchen) on the walls of the Lukhang are typically shown as Indian ascetics. Accoutrements such as the three-pronged katvanga staff - visible at the right - associate them with the Kāpāilika school of tantric Śaivism which deeply influenced the development of Vajrayāna Buddhism in India prior to its diffusion in Tibet. The abstract geometrical visions depicted in the sky anticipate 21st century abstract art which, like the practice of Dzogchen, sought to illuminate deeper levels of perceptual reality. ${ }^{\odot}$ Ian Baker

Vedic seers of ancient India, it was entirely the Desi's choice to present the generic practitioners of Dzogchen depicted in the murals as Indian ascetics rather than as Tibetans (Fig. 2). Beyond their instructional content, the Lukhang murals thus promote an ideological Indian genesis for the Dzogchen teachings, in defence against rival Tibetan claims that Dzogchen lacks legitimising Sanskrit sources. ${ }^{22}$

\section{Visual Transmission}

The Lukhang murals were created during a vibrant period of Tibetan history when cultural knowledge was on the one hand subjected to increased intellectual scrutiny and, on the other, to comprehensive, state-sponsored documentation. These initiatives began with the Fifth

22 The presence of the rși also establishes a clear case against rival Bonpo claims that Dzogchen originated in the pre-Buddhist civilisation of Shang Shung in Western Tibet. For the Bon presentation of Dzogchen, see Namdak and Myrdhin Reynolds 2006; Namdak and Dixey 2002.
Dalai Lama, Ngawang Lobsang Gyatso (1617-82)- the first leader of a fully united Tibet - who commissioned a lavishly illustrated version of a section of his Sealed and Secret Biography (gSang ba'i rnam thar rgya can) entitled the Gold Manuscript ${ }^{23}$ which, in turn, contains a chapter entitled 'Visions and their Significance' 24 that documents the Fifth Dalai Lama's own accounts of his life-long paranormal and visionary experiences. ${ }^{25}$ The Fifth Dalai Lama recounts

23 The Gold Manuscript contains 16 texts, consisting of 184 folios and five groups of illustrations with a total of 886 separate drawings on 61 illuminated folios, mostly consisting of ritual instruments and diagrams but also mandalas, cakras, and lingams, painted largely in gold on a charcoal background. The folios measure $29 \times 6 \mathrm{~cm}$.

24 The section of the Gold Manuscript entitled 'Visions and their Significance, being the elucidation of the visions recorded in the sealed volume' (rGya can gyi 'khrul snang rnams gsal bar bkod pa mThongba don (dan) contains 886 separate drawings on 55 illuminated folios.

25 The Fifth Dalai Lama refers to his paranormal visions as the flowing melody of divine beings, secret spells and wisdom at play, echoing freely through my body, speech, and mind'. See 
in his biography that he documented his visions with the 'belief that they might be beneficial to myself and others' and, especially, that they might 'guide the unititiated' and serve 'those who wish to do drawings and paintings of the heavens... and record their roamings in the Pure Lands'. ${ }^{26}$ The paintings in the Gold Manuscript were made under the Fifth Dalai Lama's direct supervision by a lay tantrika named Guru rTa mgrin between the years 1674 and 1681, the year before the Fifth Dalai Lama's death.

The Gold Manuscript of the Sealed and Secret Biography extended the scope of the written word by illustrating in minute detail the complex diagrams, ritual implements, mantras and methodological procedures of compassionate, if coercive, sorcery that the Fifth Dalai Lama had undertaken in order to solidify Tibet's political power and, in part, to repel invaders from its borderlands. Artistically, the Gold Manuscript was unique in being the earliest example of Tibetan painting in which a charcoal black background is illuminated with figures executed in silver and gold with subtle malachite, azurite and vermilion shading. ${ }^{27}$ It is also the first known instance of illustrating tantric ritual. Although not performative as a textbook of ritual magic, the Gold Manuscript nonetheless revealed the ways in which visual illustration could enhance understanding of a written text and extend its applicability.

After the death of the Fifth Dalai Lama in 1682, Desi Sangye Gyatso (1653-1705), the chief minister and de facto ruler of Tibet since 1679, continued the Great Fifth's initiatives in consolidating cultural knowledge and increasing access to Buddhist scriptures and instructional treatises through unprecedented forms of artistic production. ${ }^{28}$ In 1686 and 1688, the Desi expanded on the Gold Manuscript by commissioning two sets of 23 scroll paintings (thangka) depicting the Fifth Dalai Lama's life and visions.

He simultaneously embarked on a more ambitious and public project, collaborating from 1687 with artists and medical practitioners to transform his own four-volume

Karmay 1988, p. 28.

$26 \quad$ See Karmay 1988, p. 28.

27 See Karmay 1988. The original manuscript - painted in gold, silver and mineral pigments on charcoal blackened paper - is in the Musée Guimet in Paris. The manuscript served as a prototype for the later 'black thangka' genre of Tibetan painting, the origins of which can be discerned in 11-12th century Nepalese manuscripts.

28 In order to ensure completion of the imperial projects that 'The Great Fifth' had initiated, the Desi concealed the Fifth Dalai Lama's death for 14 years, during which time he completed the construction of the colossal Potala Palace and secretly prepared Rinchen Tsangyang Gaytso for his later installation as the Great Fifth's successor. treatise on Tibetan medicine, The Blue Beryl (Vaidūrya sngon po), into a series of 79 scroll paintings which the Desi himself described as being 'without any equivalent in the past' in their aim of providing information as lucidly as 'fruit [seen] in the palm of one's hand'. ${ }^{29}$ Following the Desi's Blue Beryl commentary on the 12th century Four Medical Tantras (rGyud bzhi), the 79 medical paintings depict human anatomy, physiology, pathology, diagnostic techniques, therapeutic methods, and pharmacological substances used in Tibet's syncretic 'science of healing' (Gso ba rig $p a$ ), which drew historically from both Traditional Chinese Medicine and Indian Ayurveda. The paintings are extraordinary, however, not only for their pedagogical illustrations of Tibetan medical science, but also for their poignant vignettes of everyday life, including a wide range of vocational pursuits, dress styles, and facial expressions. ${ }^{30}$

In a political gesture intended to establish the teenage reincarnation of the Fifth Dalai Lama as a patron of Tibet's newly systemised medical tradition, the Desi formally offered the 14-year-old Sixth Dalai Lama, Rinchen Tsangyang Gyatso, the first 62 finished paintings at the time of his enthronement in 1697. The full set of 79 medical scrolls was completed in 1703 and subsequently used as a teaching tool at Chakpori (Chags po ri) Medical College, which the Desi had established in 1696 on a hill overlooking the Potala Palace. ${ }^{31}$ Apart from representing cultural knowledge in visual form, the medical paintings were a conscious departure from prior conventions of Tibetan art, characterised by Janet Gyatso as an 'unprecedented sidelining of Buddhist elements in favor of a larger picture of the world in which religion is but one part'.32

The encyclopedic range of the secularly oriented and publically displayed medical paintings contrasted with Desi Sangye Gyatso's concurrent project of representing in artistic form Tibetan Buddhism's most esoteric meditational practices. The murals that the Desi commissioned for the Sixth Dalai Lama's private meditation chamber on the top floor of the Lukhang temple share common features with

\footnotetext{
29 Gyatso 2015, p. 62.

$30 \quad$ For an in-depth and illuminating analysis of the Desi's 79 medical paintings as they pertain to Tibetan society at the turn of the 17 th century see Gyatso 2015 .

$31 \quad$ Chakpori Medical College - along with the original set of thangkas - was destroyed during the Chinese crackdown that followed the 1959 Tibetan uprising against Chinese occupation and was reopened in Darjeeling, India, in 1992.

32 The medical paintings controversially present religious practice as a potential cause of disease and distress in the form of disputes, infighting, and ineffective magical rituals. See Gyatso 2015, p. 68.
} 


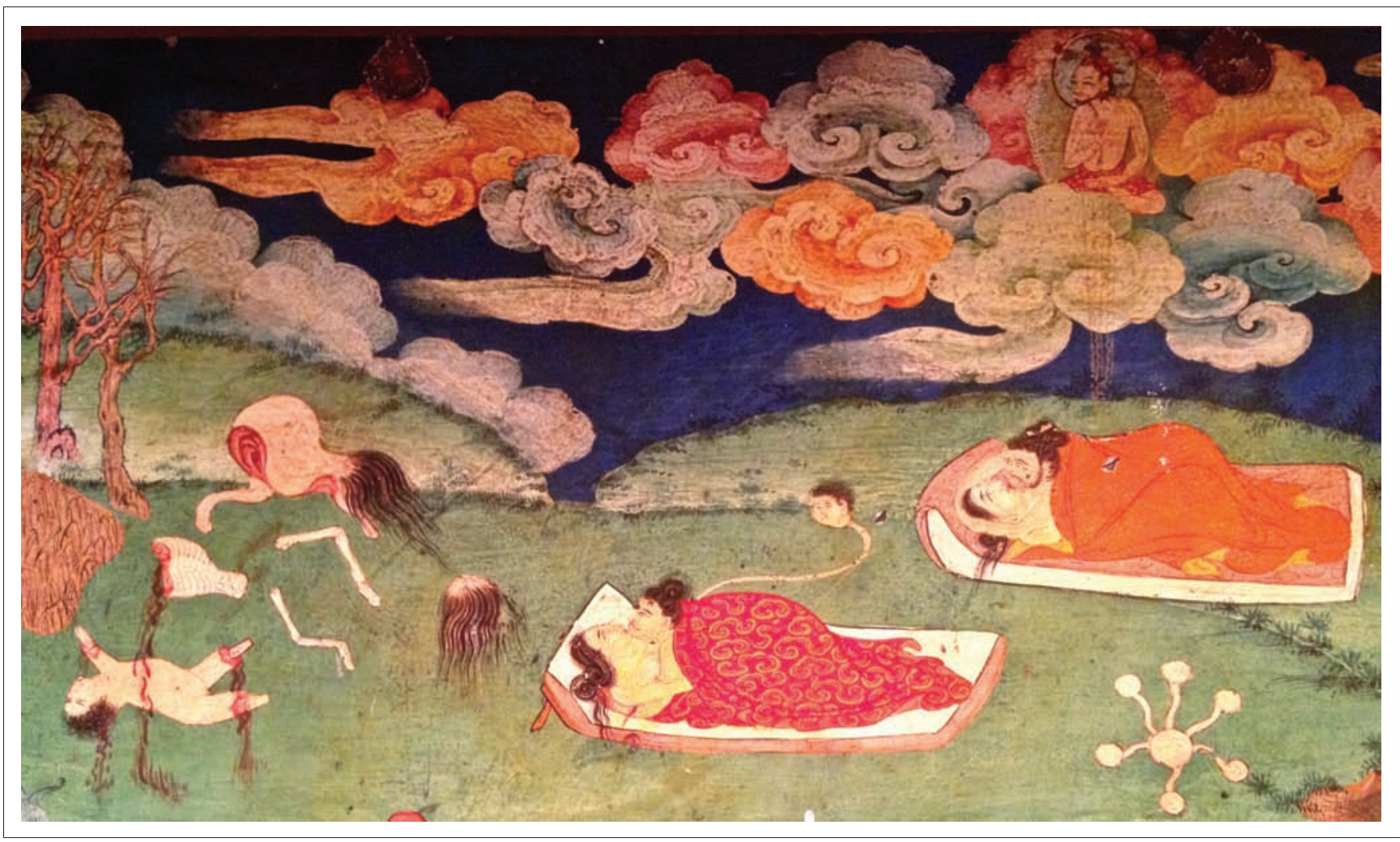

Figure 29.3 The Lukhang's northern mural includes a deconstruction of the Buddhist Wheel of Life and Rebirth. The opening vignette shows a disembodied 'soul' in the process of incarnating in a woman's womb - a choice leading to continuing cycles of birth and death, signified by the dismembered body parts at the left. The haloed figure at the upper right has opted out, as indicated by the gesture of his right hand, symbolising the Buddhist path to liberation. The image in the lower right-hand corner signifies a spermatozoa and the six realms of existence into which one may be born and is thus a reference to, and departure from, the more conventional and elaborated ways in which these realms are typically represented. ๑Ian Baker

the 79 medical thangkas, including depictions of conception, embryology, birth and death, as well as representations of the network of subtle energy channels within the human body that chart mind-body interactions and serve as a basis for both Tibetan medical theory and advanced tantric Buddhist practice. In this sense, the murals partly represent a 'medicalisation' and rationalisation of tantric practice, contextualising it within natural processes of the human body.

As with the medical paintings, the wall paintings in the Lukhang include descriptive captions, drawn from the murals' source text - Pema Lingpa's 'Compendium of Enlightened Spontaneity'. Also akin to the medical paintings, the murals feature generic representations of everyday life that serve a subliminal didactic purpose. Such images in the Lukhang murals include a miser buried under the weight of his jewel-encumbered home as well as scenes of an impassioned butcher and couples making love within a charnel ground of severed body parts (see Fig. 3). Other symbolic elements such as crystals, mirrors, and spheres of light recur throughout the murals, emphasising the encompassing Dzogchen context of self-illuminating non-dual awareness.

Whereas the medical paintings present their contents in sequential horizontal rows - read from left to right - the Lukhang murals represent the practices of Dzogchen in sinuous unbounded vignettes within surreal, and often inverted, landscapes that must be visually deciphered in order to relate them to the specific chapters of Pema Lingpa's treasure text from which the illustrations largely derive.

The mural on the north wall is particularly notable in its deconstructed depictions of the Buddhist cosmos and the 'wheel of rebirth' (srid pa'i 'khor lo) that, by convention, typically frame the entryways of Tibetan Buddhist monasteries. In the case of the Lukhang, the primal elements of the cosmos are shown as issuing from a naturalistically rendered vagina with a depiction of the mythical Mount Meru shown, without accompanying inscription, as an almost purely ornamental feature, representing a description of the universe that the current Dalai Lama has himself dismissed in favor of more scientific accounts of the cosmos. The Buddhist wheel of rebirth depicting the causes of cyclic existence is similarly deconstructed: 


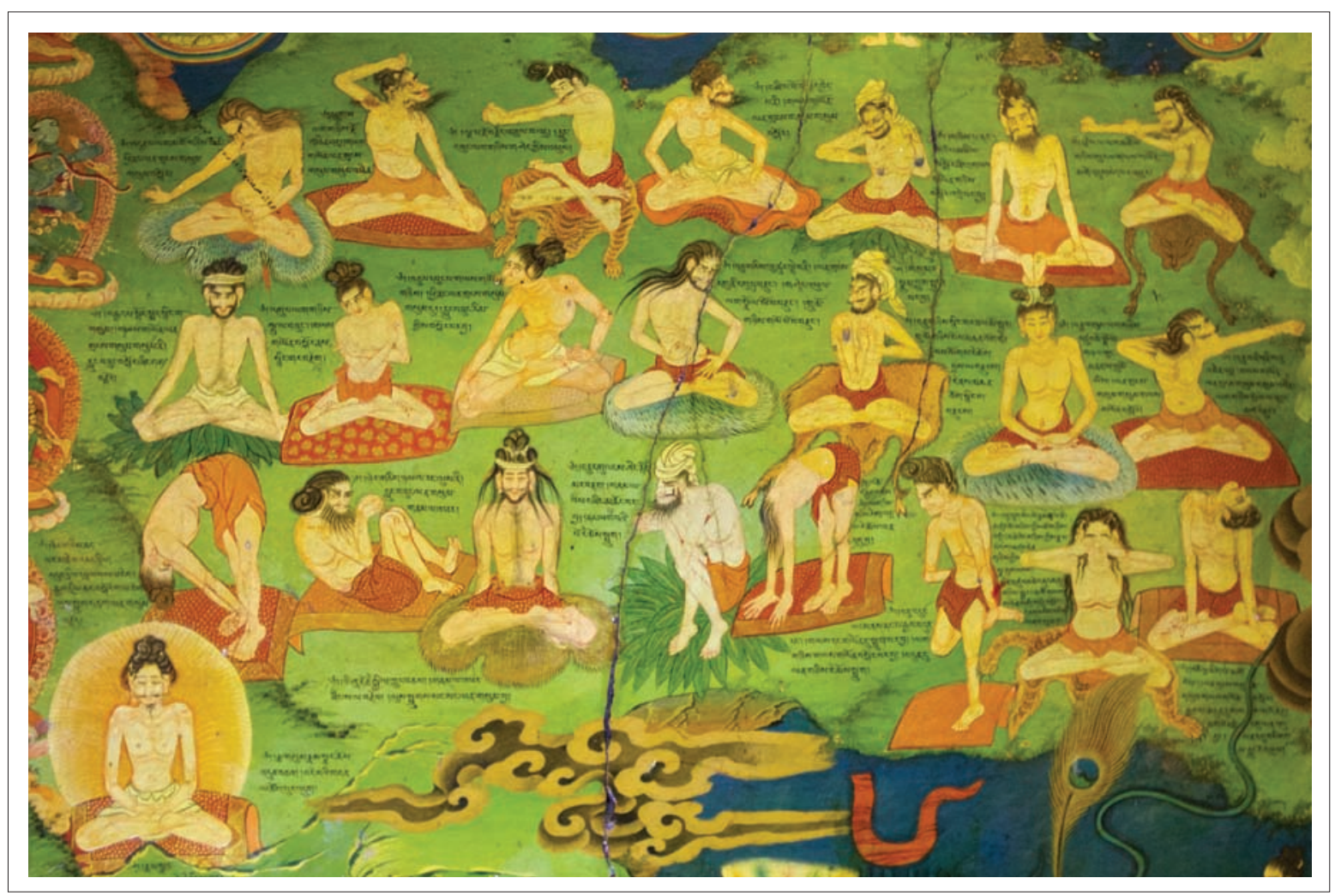

Figure 29.4 A section of the Lukhang murals illustrates Pema Lingpa's 'Secret Key to the Channels and Winds' (Rtsa rlung gsang ba'i lde mig) and includes depictions of 23 yogic exercises ('khrul 'khor) that prepare body and mind for visionary gazing practices called thod rgal ('leaping over the skull'), visions of which are pictured at the lower right. $\odot$ Ian Baker

The pig, rooster, and snake that symbolise the mental afflictions of ignorance, greed, and aggression are shown in the Lukhang murals as circling within the breast of an ordinary human being, rather than at the hub of a wheel in the hands of Mara, the Buddhist characterisation of egocentric existence. As in more traditional renderings of the wheel of life, a Buddha figure is shown nearby offering an alternate source of identification. This cycle of birth, death, and reincarnation, as well as its transcendence, is recapitulated in the opening vignette of couples making love (see Fig. 3), a reference to the 12 stages of interdependent origination that are normally depicted on the outer ring of the Buddhist wheel of life.

Throughout the Lukhang murals, generic human figures are paired with often humanistically rendered Buddhas and Bodhisattvas that emphasise the murals' overall iconographic and intellectual programme: a visual guide to the realisation of one's innate indwelling Buddha Nature. In this sense, the Lukhang murals graphically illuminate the original intent of Pema Lingpa's revealed treatise, while detailed representations of intra-ocular visionary phenomena exceed the scope of the written word. The murals were nonetheless not performative, in the sense that simply looking at them would not allow one to put them into practice without personal guidance by a realised master of the tradition. This same argument can also be made for the Desi's medical paintings that serve even today as a mnemonic course outline rather than as a comprehensive how-to guide to medical practice.

The chapter entitled 'Secret Key to the Channels and Winds' (a translation of which is appended to this chapter) from Pema Lingpa's 'Compendium' clearly reveals the limits of both words and visual representations for transmitting Dzogchen's core practices in absence of a qualified human preceptor. The chapter describes 23 sequential yogic movements, but the Lukhang murals illustrate only one position within each of the numbered exercises, rather than representing each movement's multiple stages. Although inscriptions drawn from Pema Lingpa's text accompany each of the images, a viewer would not be able to follow the practice without additional instruction any more than one could play a musical instrument simply by deciphering a sequence of musical notations. Both Pema Lingpa's source text and the illustrations on the walls of the Lukhang are, in this sense, mnemonic reminders, rather than comprehensive guides, to actual practice. Yet, as with the Desi's other highly innovative projects, no prior attempts had ever been made to illustrate esoteric practices connected with the subtle body on the walls of a temple. 
Despite Desi Sangye Gyatso's commitment to detailed realistic illustration, the encrypted nature of the images of yantra yoga ('khrul 'khor) on the walls of the Lukhang are fully in keeping with tantric Buddhism's traditional emphasis on one-to-one oral transmission. This may account for the complete omission of textual inscriptions in the section of the mural below the labelled sequence of 23 yogic movements. The images of practice illustrated in this section of the northern mural - such as a seated figure with flame erupting from his head (Fig. 8) and another gazing at a disembodied eye suspended in space (Fig. 2) - are some of the most compelling in all of Tibetan art history, but their function cannot be fully deduced even from reading Pema Lingpa's source text. Nonetheless, the effective rendering of the subjective phenomenology of these practices clearly shows the degree to which the creation of the Lukhang murals involved active collaboration with accomplished Dzogchen lineage holders. ${ }^{33}$

The convention of secrecy regarding tantric yogic practice was one reason that, unlike the medical paintings, the murals in the Lukhang remained sequestered, concealed to all but the Sixth Dalai Lama and his closest attendants. In this sense, the Lukhang murals remained a hidden treasure whose time for public revelation had not yet arrived. Even if the Desi's ultimate intention had been to confer further prestige to the Tibetan state through the revelation of an illuminated encyclopaedia of Vajrayāna Buddhism's most esoteric practices, he did not live long enough to see this materialise, as he was beheaded by Lhasa's Mongol overlord Lhasang Khan soon after the murals' completion. ${ }^{34}$ Later the same year, 1705, Lhasang Khan deposed the rebellious Sixth Dalai Lama and dispatched him, as a prisoner, to Beijing. The exiled Sixth Dalai Lama is alternately said to have died on the way to China or to have gone on to live a secret peripatetic life outside Tibet until 1746 .

Tibet's complex political circumstances at the turn of the 17 th century offer further insight into the genesis and subject matter of the Lukhang murals. Tibet's Mongolbacked and ecclesiastically disposed Gelukpa order was openly hostile to Tibet's earlier Nyingma tradition and its non-monastic teachings of 'Great Perfection'. As both secular and spiritual leaders of the Tibetan people, the Dalai Lamas nonetheless secretly practised Dzogchen, and the

33 Desi Sangye Gyatso was himself a Dzogchen initiate who received the transmission of Pema Lingpa's 'Compendium of Enlightened Spontaneity', as well as other Dzogchen practices, from Terdak Lingpa, the abbot of Oryen Mindroling, central Tibet's most important Nyingma monastery.

34 By some accounts, the Desi was murdered by Lhasang Khan's wife with whom he allegedly had an adulterous affair.

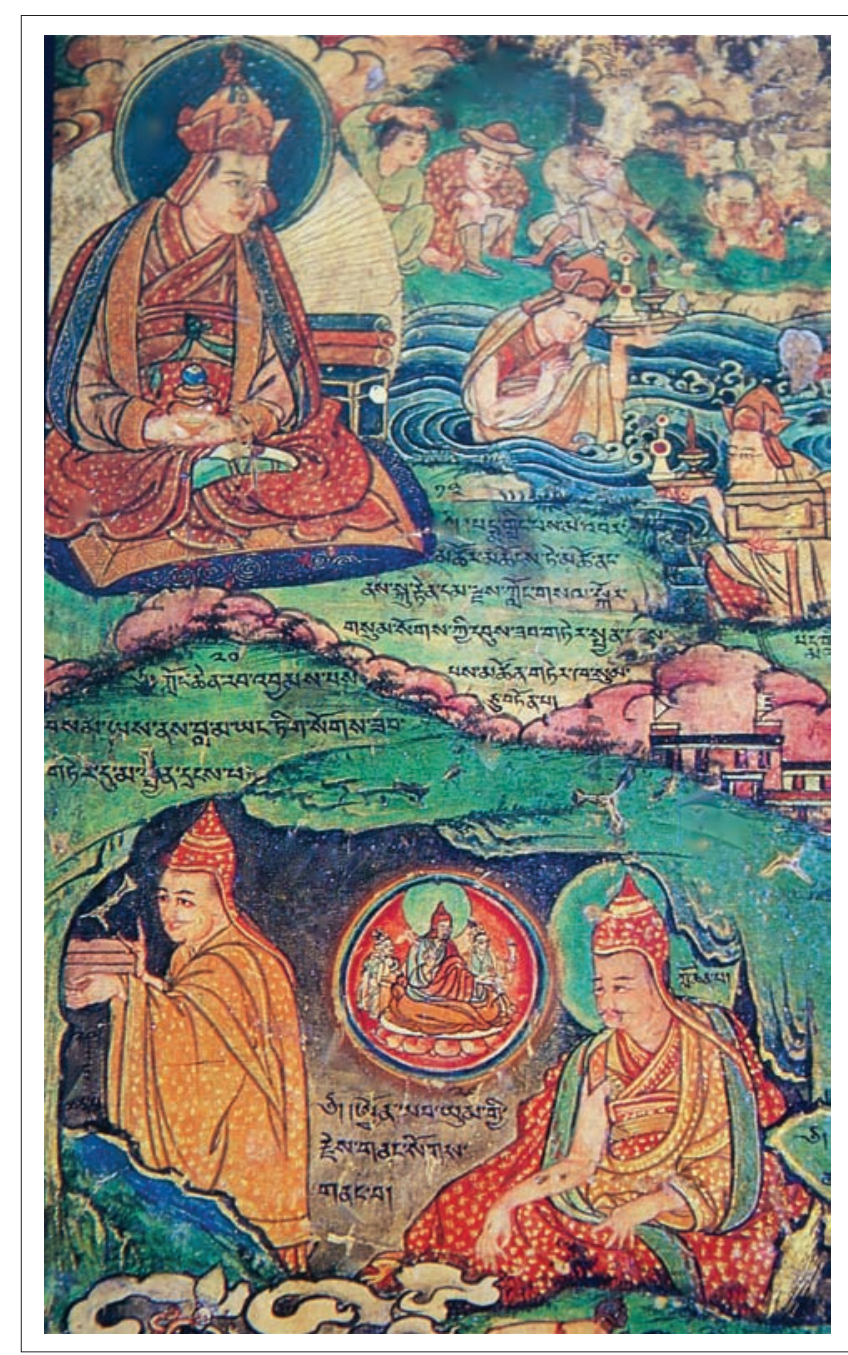

Figure 29.5 Pema Linga publicly extracting treasure texts (gter) from 'Burning Lake'. A detail from the Lukhang murals. ${ }^{\odot}$ Ian Baker

vivid murals created by Desi Sangye Gyatso within the private precincts of the Lukhang helped ensure that successive reincarnations of the Dalai Lama remained fully aware of the 'Great Perfection' practices, even if Tibet's sectarian political climate remained hostile to their dissemination.

Beyond preserving endangered esoteric knowledge in artistic form, the subject matter of the Lukhang murals also served a political function in helping to justify Desi Sangye Gyatso's clandestine and unilateral selection of Tsangyang Gyatso as the Sixth Dalai Lama, without recourse to the established protocol for identifying reincarnate Dalai Lamas. The south-east mural on the top floor of the Lukhang illustrates Tsangyang Gyatso's hereditary descent from Pema Lingpa, who is shown at multiple points in the mural extracting ter, or religious treasures, from earth and water (see Fig. 5). ${ }^{35}$

This detail from the Lukhang murals illustrates a scene in which a sceptical local governor challenged Pema Lingpa to prove his 
This panel also celebrates Pema Lingpa's previous incarnation as the revered Dzogchen master Longchen Rabjam (1308-63), who is depicted performing a tantric rite of subjugation. The dissemination of Pema Lingpa's revealed treasure teachings by Terdak Lingpa Gyurme Dorje (1646-1714) at Orgyen Mindroling, the most important monastery in central Tibet for the transmission of Dzogchen, is also vividly illustrated on the mural, as is the figure of the Sixth Dalai Lama's father, Rigdzin Tashi Tendzin, from whom Terdak Lingpa received the full transmission of Pema Lingpa's revealed teachings. Pictured next to Rigdzin Tashi Tendzin is an idealised, yet unlabelled, rendering of his son Tsangyang Gyatso, the Sixth Dalai Lama, as a temporal and religious monarch surrounded by devoted subjects (see Fig. 6). This image is entirely unprecedented - as well as politically expedient - in showing a figure of Amitābha, the Buddha of Infinite Light, emerging from the Sixth Dalai Lama's head turban, linking him iconographically to Tibet's first emperor and 'dharma king' Songtsen Gampo (617-49). Such a bold and compelling visual account of Rinchen Tsangyang Gyatso's spiritual and hereditary origins would have helped protect both him and the Desi from potential detractors, establishing the Sixth Dalai Lama as a legitimate embodiment of Avalokiteśvara, the Bodhisattva of Supreme Compassion. ${ }^{36}$

All of Desi Sangye Gyatso's works reveal an unusually creative and interpretive mind using art to convey cultural, medical, and religious practices beyond the limits of both written expression and iconographical conventions. Although the Lukhang murals represent an unprecedented moment in Tibetan intellectual history- portraying knowledge at the cutting edge of innovation and creative imagination and revealing complex cultural and socio-political agendas - the primary intent of this chapter is to clarify the nature of the practices and body-based spirituality that the Lukhang murals depict.

authenticity by retrieving a treasure text from an underwater grotto in front of a large audience. Pema Lingpa declared that if he was genuine, he would return with the text before his butter lamp extinguished. If he were a fraud, he would die in the water. He dived in and returned with a small box and a sculpture, his butter lamp still burning.

This idealised portrait of the Sixth Dalai Lama is still more striking in its inclusion of ritual objects linking him to the other two principle Bodhisattvas widely represented in Tibetan art. A religious text and a sword are pictured at his left, connecting him to the Bodhisattva of transcendental wisdom Manjusri, while a vajra (dor je) to his right links him with Vajrapani, the Bodhisattva of wrathful, yet compassionate, power.

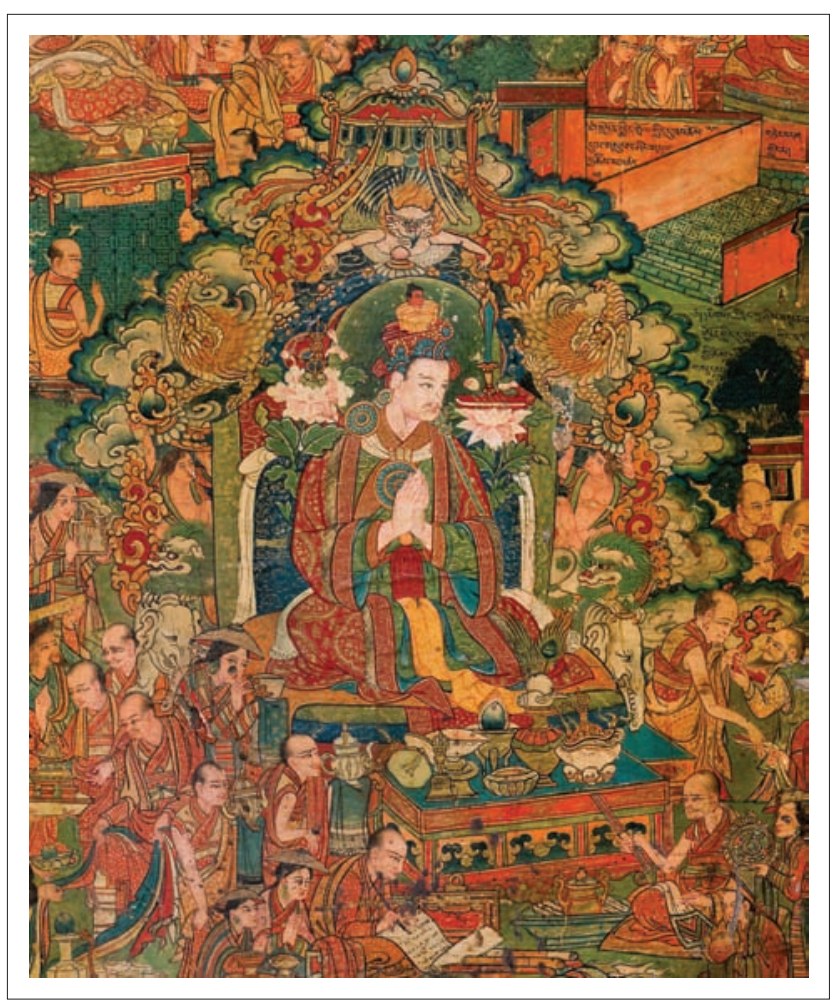

Figure 29.6 This detail from the south-east corner mural of the Lukhang temple presumably shows Tsangyang Gyatso, the Sixth Dalai Lama, as a 'Bodhisattva king', modelled on the iconography of Avalokiteśvara holding the wishfulfilling gem of supreme compassion in his joined palms, and with the accoutrements of wisdom and spiritual power emerging from lotuses at his shoulders. ${ }^{\odot}$ Ian Baker

\section{Preludes to Perfection}

Advanced practice in Vajrayāna, or Tantric Buddhism, is customarily preceded by foundational practices called Ngondro (sngon 'gro), designed to transform the adept's subjective experience of reality. These generally consist of development phase (bskyed rim) ${ }^{37}$ methods of visualisation and mantra recitation that reorient consciousness and develop concentration and insight. These are customarily followed by completion stage ( $r d z o g s$ rim) practices based on a metaphysical anatomy of channels, winds, and subtle essences within the human body. These methods lead, in turn, to the enlightening realisation of the inseparability of outer and inner experience. Dzogchen differs from tantra in maintaining that enlightenment is spontaneously present as humankind's innermost nature and needs only to be recognised. The foundational practices in Dzogchen thus forgo graduated liturgies and elaborate rites of trans-

37 For a concise presentation of the development stage (bskyed rim) of Mahā Yoga associated with sngon 'gro, see Dudjom Rinpoche 1991, pp. 275-83. See also ch. 18 in Kongtrul 2005. 


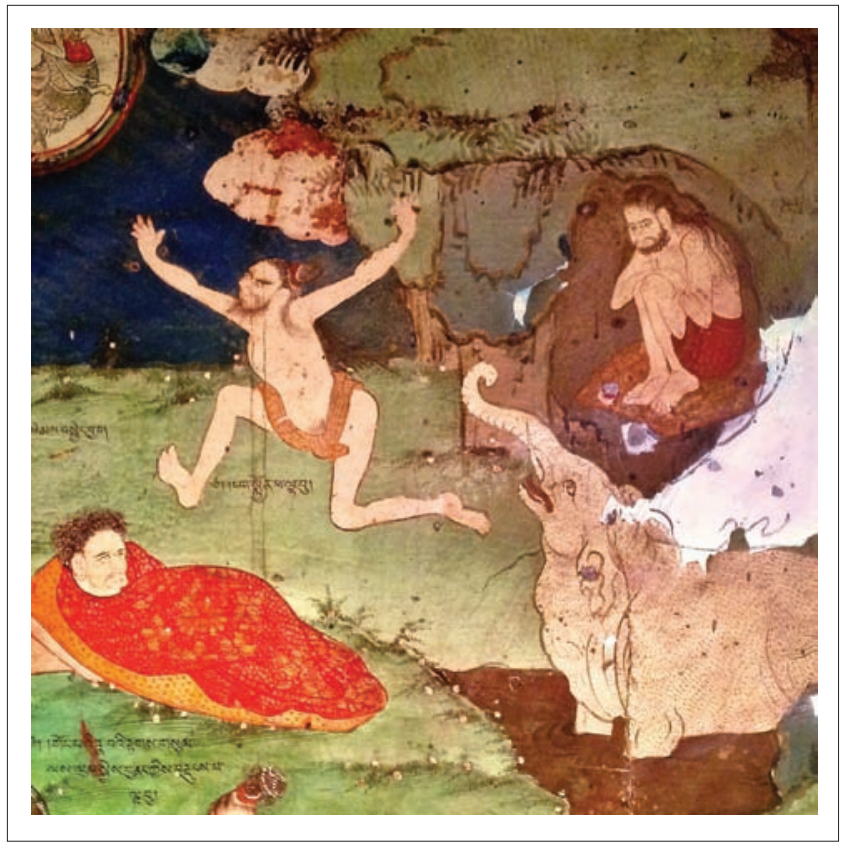

Figure 29.7 This detail from the Lukhang's western mural shows a Dzogchen yogin acting out interior states of consciousness in a process called Korde Rushen ('khor 'das ru shan), 'distinguishing Samsāra from Nirvāṇa'. The elephant emerging from a quagmire symbolises the freedom of consciousness that the practice facilitates. ${ }^{(C)}$ Ian Baker

formation and focus instead on embodying primordial awareness ( $r i g ~ p a)$ in every conceivable circumstance.

Divided into Outer, Inner, Secret, and Ultimately Secret methods for distinguishing the spontaneous self-liberating awareness (sem nyid) of Nirvāṇa (T: mya ngan 'das) from the bounded mental habits of Samsāra (T: 'khor $b a$ ), Dzogchen's foundational practices are called Korde Rushen ('khor'das ru shan) and are normally undertaken in wilderness settings. Although their purpose is to induce a radical reorientation of consciousness - distinguishing the contents of conscious from consciousness itself - the methods by which this is achieved involve pushing both body and mind beyond all habitual limits. In the practices of Outer Rushen, the adept is instructed to physically act out conjured existences from heavens to hells and thus to recognise the self-created nature of conditioned existence. These practices are illuminated on the western wall of the Lukhang murals in images such as that of a yogin shown leaping like a rogue elephant through a shape-shifting landscape of blues and greens (see Fig. 7). As a Dzogchen treatise entitled 'Flight of the Garuda', contemporary with the Lukhang murals, instructs:

With the conviction that Samsāra and Nirvāna are of one taste... walk, sit, run and jump, talk and laugh, cry and sing. Alternately subdued and agitated, act like a madman. Finally abide in a state of ease and contentment... .
Practising in this way your realisation becomes as vast as the sky and your meditation naturally radiant.... Without reference points, prejudice or attachment, your actions become spontaneous and saintly, making no distinction between self and others. Detached from your utterances, your speech is like a melodious echo. Without desire for anything at all you are like a celestial eagle soaring through space, or like a fearless and intrepid lion... free from the very beginning, like bright clouds in the sky. ${ }^{38}$

When body and mind have exhausted their capacity for consciously directed dramatic expression, one rests in a state of lucid relaxation ( rnal du ba), corresponding to the śavāsana, or 'corpse' pose, of hațha yoga.

By alternating unrestrained enactment of the imaginative projections of the mind with pristine objectless awareness, the practitioner of Outer Rushen discovers how Samsāra, the state of dualistic distraction, and Nirvāna, open selfless presence, emerge from the same 'primal purity' ( $k a \mathrm{dag}$ ) beyond being and non-being. As Padmasambhava explicates in a treasure text entitled 'Liberation Through Seeing with Naked Awareness' (Rig pango sprod gcer mthong rang grol):

Saṃsāra and Nirvāṇa have no difference other than being unaware or aware [of the intrinsically undivided nature of reality]... . Since we are not deluded by perception but by fixation, Liberation naturally occurs when we recognise that fixated thoughts are only mind grasping at its own empty manifestations.

Through the cathartic improvisations ${ }^{39}$ and physical actions of Outer Rushen, the practitioner releases all inhibitions and attachments and realises a freer dimension of being, based on the mind's essential and abiding nature rather than its transient expressions.

The practices of Inner Rushen ${ }^{40}$ focus attention on six areas along the central axis of the physical body and soles

38 See Dowman 1984. For a detailed account of the relation of Pema Lingpa's texts to the different sections of the Lukhang wall paintings, see Winkler 2002, pp. 321-43.

39 The methods of Outer Rushen recall the creative and empowering dramatisations of psychic contents used in therapeutic modalities such as Psychodrama, defined by its founder, Dr J.L. Monroe, as 'the science which explores the truth by dramatic methods'. Monroe was the author of an influential book, The Theatre of Spontaneity (1924), which addresses the cathartic effects of uninhibited self-expression in therapy and personal growth.

40 The precise instructions for Korde Rushen practices vary between different Dzogchen lineages. In some, the 'Purification of the Six Lokas' as described here is performed prior to the Outer Rushen described above. As with all aspects of Dzogchen, the key point is never technique but the end result: integrating awareness of the mind's innermost non-dual nature within all 
of the feet correlated with inhibiting psychological potentialities and the karmic traces of past actions. Envisioning associated 'seed-syllables' (bija mantra) ${ }^{41}$ at each of the six points, one clears them of all subconscious residue with the intonation and visualisation of blazing white, red, and blue light resounding from the seed mantras $\mathrm{Om}, \mathrm{Ah}$, Hum, representing the triune totality of pristine awareness. Consciousness thus shifts from identification with the body's materiality to its underlying luminescence (nang gsal). ${ }^{42}$ As with the practice of Outer Rushen, sessions focused on the physical body are alternated with motionless periods of concept-free awareness in which thoughts dissolve within the encompassing space of primordial awareness (rig pa).

Inner Rushen's clearing of subconscious somatic obscurations prepares the body for the practices of Secret Rushen, which commence with adopting a highly strenuous isometric posture - the 'position of the vajra' ( $r d o$ rje'i 'dug stang) - which, supported by associated mental imagery, pushes body and mind into a state of positive eustress, leading to the emergence of adaptive mental and physical capacities. Standing tensed with heels together, knees stretched out to the sides, chin to larynx, and the hands palm to palm above the crown of the head while visualising oneself as an indestructible blazing blue vajra ( $r$ do rje), the practitioner observes the flow of energy and sensation within the body while pushing through barriers of pain and exhaustion. The position is held until the body physically collapses and then is continued on the ground to whatever degree is possible. Then, with the resounding of the seed-syllable Phat, one lies down in a state of unconditioned concept-free awareness. When thoughts arise, one repeats the process in continuing cycles of effort and repose. More than any other Dzogchen practice, the 'vajra posture' engages the physical body in ways designed to alter

circumstances and experience.

41 The syllables $\mathrm{Ah}, \mathrm{Su}, \mathrm{Nri}$, Tri, Pre, and $\mathrm{Du}$ correlate with the forehead, throat, heart, navel, base of the trunk, and soles of the feet. The upper five centres are also associated with seed-syllables representing the Five Elements. Early reference to practices associated with the recitation of the panca bhüta (five element) bija mantras (Ham, Yam, Ram, Vam, and Lam) can be found in the ShriJabala Darsana Upanishad, composed between 200 вСЕ and $200 \mathrm{CE}$.

Photon emission associated with bioluminescence within humans and other species has been identified as a side-effect of metabolic reactions, the result of highly reactive free radicals produced through cell respiration interacting with free-floating lipids and proteins. The 'excited' molecules that result can react with chemicals called fluorophores to emit photons (The Guardian, 17 July 2009). the flow of psychosomatic energies and to embody experientially the mind's capacity to transcend and gain from physiological stress as it identifies ever increasingly with the essence of consciousness, rather than its adventitious forms including the illusory notion of an abiding self. ${ }^{43}$

The body practices of Secret Rushen are followed by practices of sound and vibration in which a blue seed-syllable Hum is intoned and visualised as multiplying until small Hums fill the entire universe. The syllables and sounds of Hum then fill one's entire body propelling it imaginatively through space. At the end of the session one again lies down as in the practice of the body and rests in open presence. When thoughts arise, one begins the practice anew, using the primal energy represented by the seed-syllable Hum to alter habitual perceptions and conceptions of reality. According to the texts, signs of accomplishment include physical bliss, mental lucidity, and non-conceptual awareness.

The subsequent mind practice of Secret Rushen uses the seed-syllable and sound of $A h$ to enter into direct experience of the pure potentiality, or emptiness, that underlies all appearances. Dissolving all perceptions into effulgent light, one remains in a unified state of luminous cognition, beyond conceptions of time and space. The quiescent culmination of the mind component of Secret Rushen forms the basis for Ultimately Secret Rushen in which the energetic currents of one's inner being are expressed dynamically 'in order to free what has been stabilised'. Spontaneously manifesting as a wrathful tantric deity representing the creative volatility of sensation, thought, and emotion, one stands with hands formed into horned $m u d r a \bar{s}$, pivoting from left to right on heels driven into the earth. With eyes rolling in the sky, one emits loud thought-subduing laughter from the deepest core of one's being, filling all space with the syllables and sounds of $\mathrm{Ha}$ and $\mathrm{Hi}$. As in all Rushen practices, the body is used to its fullest potential to bring the mind to an innate state of lucid, all-pervading awareness, the foundation for all subsequent Dzogchen practices based on the existential ideal of discovering ultimate freedom within the flow of ordinary experience.

43 The development of increased mental and physical capacities through pushing through habitual limits is known in biology as hormesis, a process whereby beneficial effects such as increased strength and resilience, growth, and longevity can result from deliberate and systematic exposure to therapeutic stress. 


\section{Flowing Wholeness}

A seminal chapter of Pema Linga's treasure text 'Compendium of Enlightened Spontaneity' is illustrated on the north wall of the Lukhang temple, further illuminating the role of physical practices in Dzogchen. Entitled 'The Secret Key to the Channels and Winds' (Rtsa rlung gsang ba'i lde mig), ${ }^{44}$ the chapter focuses on methods of self-cultivation that view the body as a vehicle for realising a liberated condition beyond all physical and conceptual limits. (See the Appendix to this chapter for an illustrated translation of Pema Lingpa's 'Secret Key'.) Based on the Dzogchen formula of 'Four Sessions for Realising Buddha Nature' (thun bzhi sangs rgyas ro mnyam pa nyid), the interconnected practices are undertaken at dawn, daytime, dusk, and night and reframe the Six Yogas of tantric tradition in the context of Dzogchen's radical view of non-duality. 45

Unusually for a Dzogchen treasure text, the chapter begins with a description of 23 yogic exercises ('khrul'khor) that, combined with specific breathing techniques, ${ }^{46}$

44 Rdzogs chen kun bzang dgongs'dus, vol. 2, pp. 33-40. 'Winds and channels' (rtsa rlung. Skt: nādī vāyu) refer to tantric representations of the body as a flow of subtle energies that, harnessed and controlled through yogic practice, lead to illuminating states of awareness. The principal energy channels represented in the Lukhang murals are the body's central channel (rtsa dbu ma, Skt: avadhüti) and the paralleling 'solar' and 'lunar' side channels (rtsa ro ma and rtsa rkyang ma) (see Figs 11 and 15). A translation of 'The Secret Key to the Channels and Winds' is appended to this chapter, illuminating the fundamental dynamics of mind and body at the heart of the Dzogchen tradition and the ways in which primordial unitary awareness (rig pa) arises vibrantly and unconditionally in response to physiology and perception pushed beyond their accustomed limits, whether in states of waking, sleeping, dreaming, or near-death experiences. In contrast with Kagyu, Sakya, and Geluk presentations of the Six Yogas, Pema Lingpa's 'Secret Key' emphasises the Dzogchen approach of 'self-liberation' rather than that of transformation (see also n. 7). The order of the 'four sessions' varies between $\mathrm{Dz}$ ogchen lineages. The Yeshe Lama, for example, describes them as follows: 'Before sunrise, one focuses on a white $A h$ emerging in the sky before one from the white $A h$ at the heart. During the daytime, one meditates on the natural visions of thod rgal. At dusk, one practises gtum mo. During the night, one withdraws the senses into a luminous $A h$ in the vase of the heart (she bya bum 'jug)'.

46 The breath or vital energy (rlung, Skt: präna) of the body is often likened to a horse and the mind to the rider of the horse. The movements of 'khrul 'khor, sometimes called Yantra Yoga, are normally performed with the breath held in the lower abdomen 'like a vase' (bum can, Skt: kumbhaka) in order to direct the prānic winds into the body's central meridian and alter the are held to clear the pathways of the channels $(r t s a)$ and activate the flow of awareness through the body's central meridian (rtsa dbuma) (see Fig. 4). The exercises culminate in the seven-point meditation posture (rnam snang chos bdun $)^{47}$ that forms the basis for the subsequently described evening practice of 'fierce heat' (gtum mo) in which the physical senses are drawn inward towards the experience of 'four joys' (dga'ba bzhi, Skt: caturānanda) at specific points along the body's central axis, giving rise to the self-transcending rapture of co-emergent bliss and emptiness (bde ba'i stong pa nyid). ${ }^{48}$

The text goes on to describe practices of lucid sleep and dreaming - 'retaining wakefulness in the vase' - whereby the habitual divisions between conscious and subconscious states are gradually overcome as the inner winds (rlung, Skt: prāna) resolve at the heart into all-pervasive Luminosity ('od gsal). ${ }^{49}$ Pema Lingpa's text next describes 'reviving natural awareness at dawn', a method involving the propulsion of the heart-syllable Hum through the crown of the head to a bow's length in front and above until it naturally dissolves and becomes co-extensive with infinite space, the ultimate posited nature of mind and body. The text then introduces the daytime practice of thod rgal, or 'leaping over', by which the mind, through attending to

flow of consciousness. When combined with the 'Four Sessions for Realising Buddha Nature', the practices of 'khrul 'khor are normally undertaken before the evening practice of gtum mo or in the early morning before the practice of thod rgal. In thod rgal, however, the practitioner refrains from any manipulation of the prānic winds so as to directly engage primary non-dual consciousness. This is accomplished through an alternative network of 'light channels' ('od rtsa).

47 The seven points consist of the legs in full lotus position, the spine erect, the shoulders broadened, the neck bent slightly forward, the hands in the gesture of equanimity (with the right hand resting on the left palm), the tip of the tongue touching the palate, and the gaze directed beyond the tip of the nose.

48 The bliss that is cultivated through the practice of gtum mo represents the transformation of dualistically oriented desire into innate rapture beyond subject or object (bde ba chen po, Skt: mahäsukha, sahajananda). The process is described through the experience of four progressive states of bliss, each associated with a different energy locus along the body's central axis, and culminating in open enstatic awareness beyond divisions of pleasure and pain.

49 The practices of inner yoga described in the chapter "The Secret Key to the Channels and Winds' are elaborated in other chapters of 'Compendium of Enlightened Spontaneity' such as one entitled 'The Secret Practice of Noetic Fire (gtum mo)' and another on 'taking desire as the path' entitled 'Churning the Depths of Samsāra'. For a detailed description of the practice of gtum mo, see Yeshe 1998. 


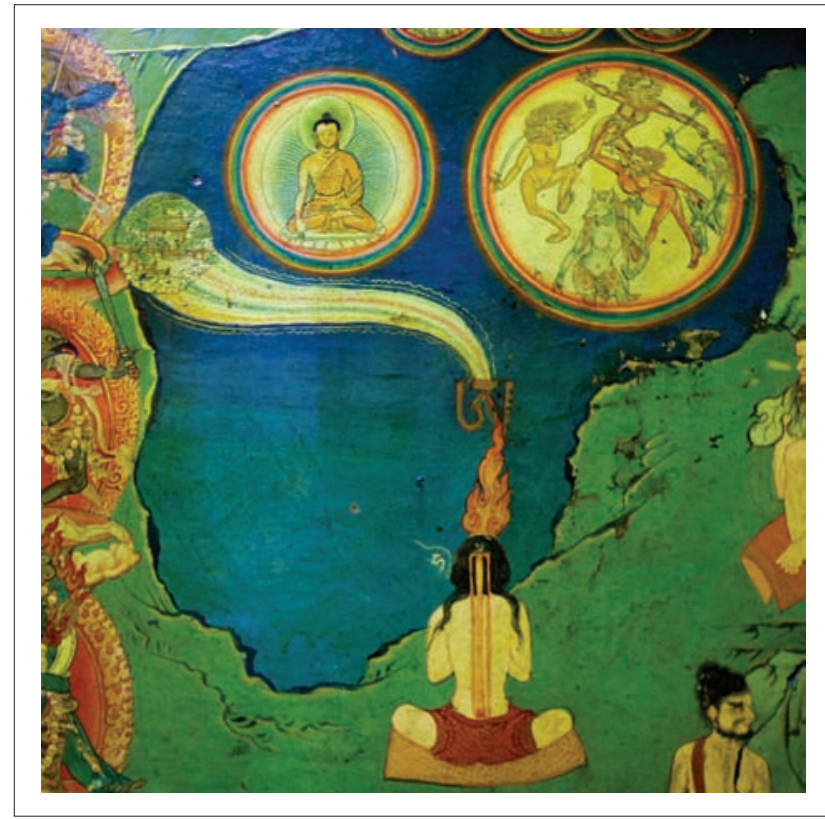

Figure 29.8 This detail from the Lukhang's northern mural appears beneath the section of the wall that illustrates 23 yogic exercises that prepare the mind and body for meditation and interior yogic practices (see Fig. 4). This image illustrates the actualisation of Buddha Nature (de gshegs snying po, Skt: tathāgatagarbha) through the practice of 'fierce heat' (gtum mo) and the ejection of consciousness ( $p h o b a$ ) to a paradisiacal Buddha Realm. $\odot$ Ian Baker

spontaneous displays of numinous photonic spheres (thig le), ${ }^{50}$ becomes coextensive with the expanse of reality (chos kyidbyings, Skt: dharmadhātu) and the body, at the time of death, dissolves into rainbow light, the subtlest expression of the five elemental energies held to comprise the manifest universe (see Figs 2 and 12).

While all of the meditative practices described in Pema Lingpa's text involve the support of the physical body, the sequence of 23 hatha-yoga-related movements illustrated on the northern wall of the Lukhang are the most revealing. While analogous exercises are described in commentaries to the Hevajra Tantra and other early Vajrayāna Buddhist works for facilitating the transformative flow of kundalini

The Tibetan word thig le (Skt: bindu) has multiple meanings depending on context. Within thod rgal practice, thig le refers to spheres of multicoloured light that mutate into an infinite variety of intermediary forms held to represent the inherent dynamics of primordial awareness (rig pa). As entoptic phenomena (visual effects whose source is within the eye itself as images cast upon the retina), thig le also bear comparison with muscae volitantes-'floaters' that can spontaneously arise within the visual field as luminous chains or drifting orbs - as well as with phosphenes, subjective perceptions of light in the absence of light actually entering the eye, such as when one presses on one's eyeballs.

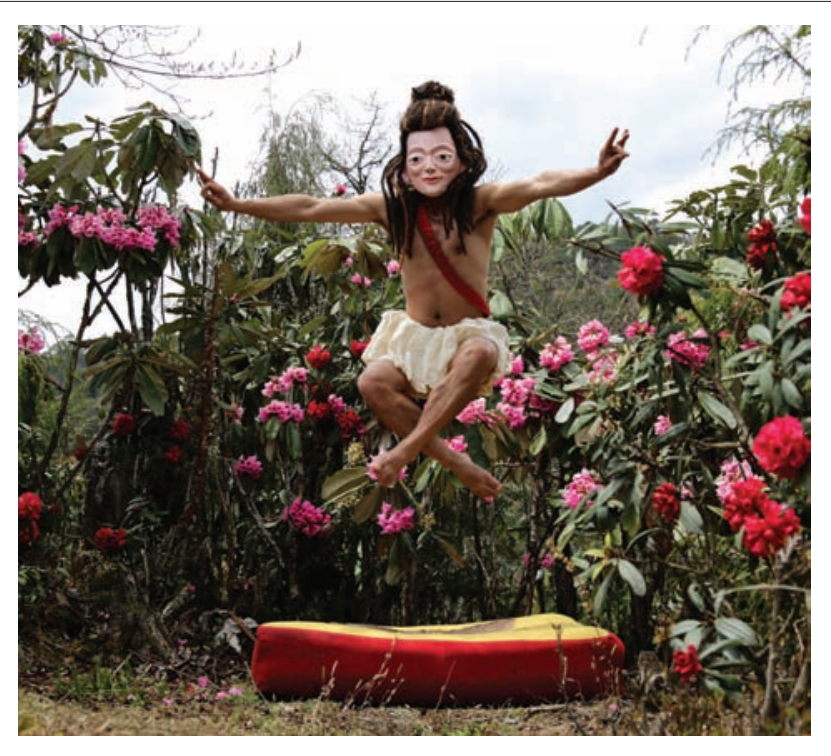

Figure 29.9 The practices illustrated on the walls of the Lukhang remain a living tradition in Bhutan, where a Nyingma yogin - concealing his identity behind a mask - demonstrates the sequence of 23 yogic exercises ('khrul'khor) central to Pema Lingpa's 'Secret Key to the Channels and Winds'. The movement shown in this contemporary photograph is a controlled fall (bep) that concentrates energy in the body's central channel (susumnā) to facilitate the practice of 'fierce heat' (gtum mo). ${ }^{\odot}$ Ian Baker

(gtum mo, Skt: canḍālī) through the body's central channel (rtsa dbuma, Skt: avadhüti), no definitive records exist of the inclusion of such practices in early Dzogchen (see Fig. 9).

Nonetheless, rtsa rlung 'khrul 'khor forms a major part of the Dzogchen gter ma tradition from the 11th century onwards, when practices based on the body's 'inner mandala' (nang pa'i dkyil 'khor) of subtle energy channels were introduced in Tibet through the Kagyu and Sakya lineages. The Nyingma tradition of inspired revelation continues to this day, however, in the appearance of works such as the 'Union of Sun and Moon' ('khrul 'khor nyi zla kha sbyor gyi dgongs 'grel dri med nor bu'i me long), credited by the Tibetan scholar and meditation master Chogyal Namkhai Norbu to Vairocana, a Tibetan contemporary of Padmasambhava, who lived during the 8th century. The text's detailed presentation of 108 sequenced movements, linked by precise breathing methods for directing the flow of internal energy, includes postures (asana) that are otherwise known only in works of hatha yoga that appeared in India from the 15 th century onward. A verifiable historical source for the text translated and published by Namkhai Norbu as Yantra Yoga: The Tibetan Yoga of Movement ${ }^{51}$ sion of Yantra Yoga ('khrul 'khor) from Padmasambhava who, in 


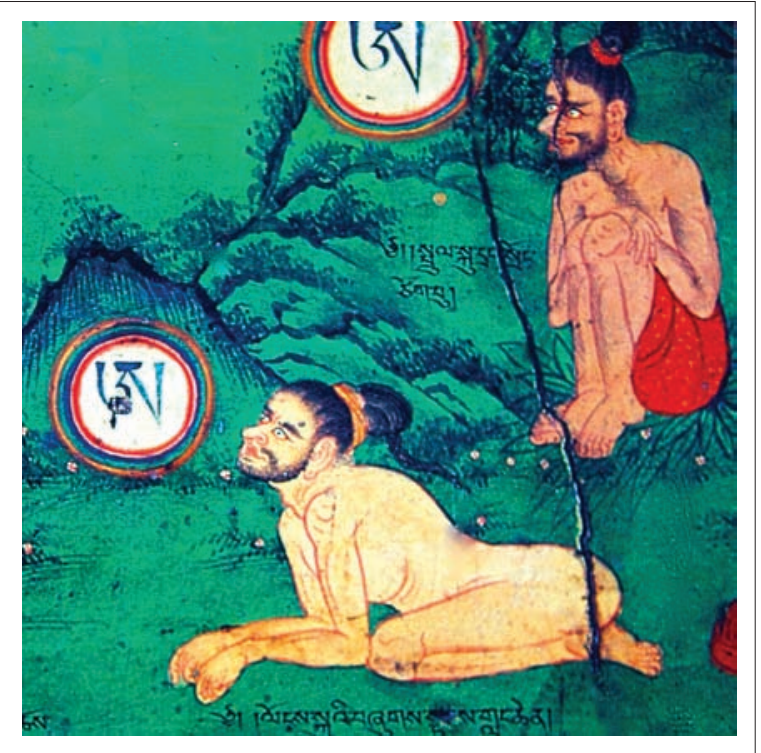

Figure 29.10 “The Dzogchen 'leaping over the skull' (thod rgal) postures of elephant and sage, as illustrated on the western mural of the Lukhang temple in Lhasa, Tibet, $c .1700$. The seed-syllable $A h$ in the rainbow-encircled nimbuses symbolises the mind's primordial 'alpha' nature. ${ }^{\odot}$ Ian Baker

would change not only current understanding of the history of postural yoga, but would also clearly identify the existence of $r$ tsa rlung and 'khrul 'khor practices in Tibet prior to their introduction through the Kagyu and Sakya lineages during the second diffusion of Vajrayāna that began in the 11th century. In any event, the complexity and diversity of Yantra Yoga ('khrul'khor) in Tibetan Buddhism suggests that, like Tibetan medicine, it was an eclectic and syncretic tradition drawing on methods and practices derived from multiple cultural sources. ${ }^{52}$

Pema Lingpa's 'Secret Key to the Winds and Channels' includes many of the same movements described in Vairocana's 'Union of Sun and Moon'. It also bears strong similarities to the 'khrul 'khor practices promulgated by Pema Lingpa's preceding incarnation, Longchen Rabjampa (Klong chen rab 'byams pa) (1308-64), as well as those

turn, had received it from a Nepalese mahāsiddha named Humkara who had himself learned it from the great adept Shri Simha, an early Dzogchen lineage-holder who had spent considerable time at Mount Wutai in China. The esoteric movements of 'khrul 'khor as practised in Dzogchen resemble not only Indian hatha yoga but also Taoist-Chan Buddhist methods of Qigong that were current at Mount Wutai within The East Mountain Teachings. Further research may thus indicate syncretic origins for Tibet's rtsa rlung and 'khrul 'khor practices. For elucidation of 'khrul 'khor within Tibet's Bon tradition, see Wangyal 2011; Chaoul-Reich 2006.

See Baker 2017 and the forthcoming Tibetan Yoga: Secrets from the Source. codified in the 'Heart-essence of Infinite Expanse' (Klong chen snying thig), a mind treasure revealed by the scholar and adept Jigme Lingpa (1730-98). ${ }^{53}$ As all traditions of Dzogchen maintain, the practice of rtsa rlung and 'khrul 'khor can result in improved health and well-being and prepare the body for inner tantric practices such as gtum mo, but their primary function within Dzogchen is to coordinate the body's psychosomatic winds (rlung, Skt: prāna) so that the nature of awareness becomes ever more manifest and embodied through the Dzogchen contemplative techniques of thod rgal, or 'leaping over the skull' (Figs 2, 10 and 12).

\section{The Body of Light}

'The Secret Key to the Channels and Winds' presents the 'khrul'khor exercises as preparations for the contemplative practices of lhun grub thod rgal, or 'leaping over the skull into spontaneous presence, ${ }^{54}$ which include prescribed body postures, breathing techniques, and associated gazes (Skt: $d r s ̦ t i$ ) for shifting consciousness from left- to right-brain activity, correlated with unitary awareness and the dissolution of distinctions between subject and object. Using the support of sunrays and the sky, awareness expands from restricted egocentric consciousness to a self-transcendent totality and the spontaneous display of what is held to be intrinsic non-dual reality (see Figs 2 and 12). The physical body is upheld as the vehicle by which awareness eventually expands to encompass all dimensions of being, described in Vajrayāna as the triune 'bodies' (sku gsum, Skt: trikāya) of Dharmakāya, Sambhogakāya, and Nirmānakāya, referring respectively to infinite undifferentiated totality, intermediate visionary experience, and manifest temporal reality.

Specific body postures and gazes are associated with each of the three kāyas, and the practitioner may freely shift between them during a single session of contemplation while maintaining 'three-fold motionlessness of body, eyes, and consciousness'. As further described in Pema Lingpa's treasure text, the Dharmakāya posture of a seated lion involves squatting on the ground with the soles of the feet together and the hands resting on the ground in front in vajra fists (with the tips of the thumbs touching the base of the ring finger). The upper body is extended upwards with the chin tucked slightly in and the spine and back of

53 For an updated history of 'khrul 'khor in Vajrayāna and Tibetan history, see Baker 2017.

54 See Namdak and Dixey 2002; Chagme 200o; Baker 2011, pp. 11621. 

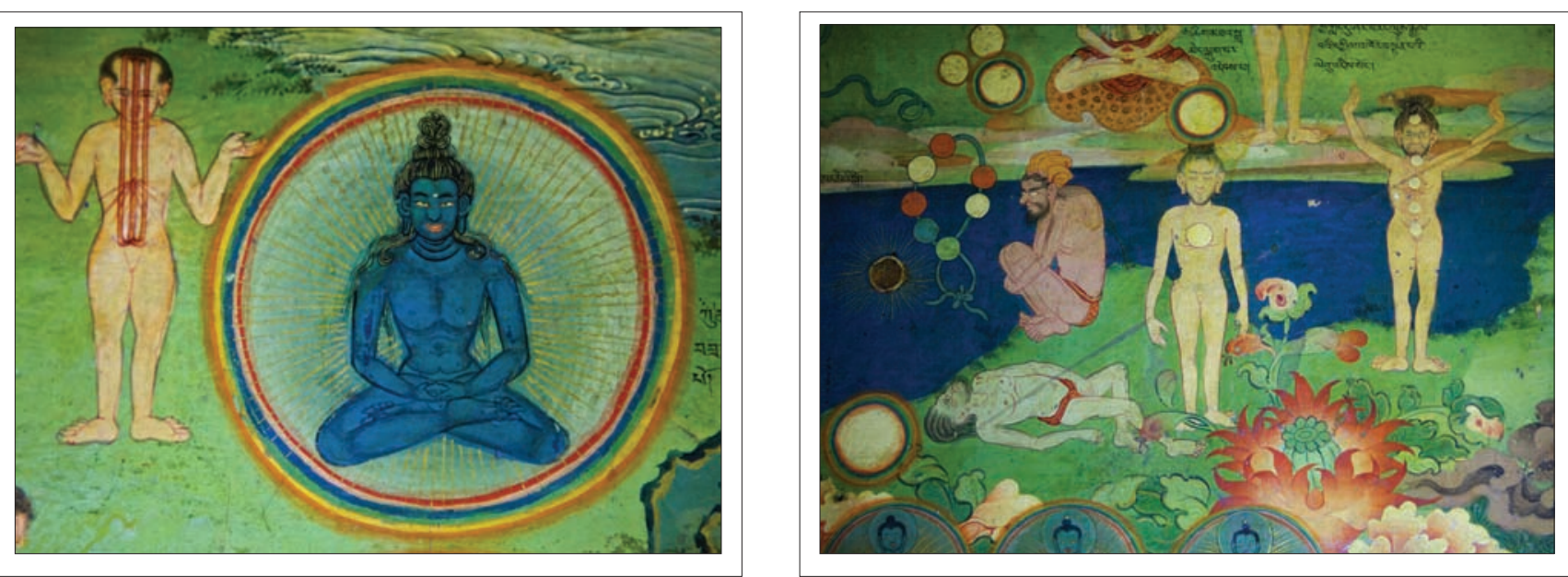

Figures 29.11-12 The images in the Lukhang murals represent processes of physical and psychological illumination in which the practitioner of Dzogchen awakens to his or her indwelling Buddha Nature, experienced as a transpersonal dimension of bliss, clarity, and compassion. The paintings, completed at the turn of the 17th century, preserved a deeply embodied and assessable form of spiritual practice, independent of Tibet's monastic and ecclesiastical traditions. ${ }^{\circ}$ Ian Baker

the neck straightened so as to allow the free flow of vital energies through the cranial arteries and associated light channels' connecting the heart and eyes. With the breath extended outward through gently parted teeth and lips, the eyes are rolled upwards past an imagined protuberance at the crown of the head into the limitless expanse of sky.55

In the Sambhogakayya posture of a reposing elephant (Fig. 10), one lies down with the knees tucked beneath one's chest, toes extended behind, elbows on the ground and hands placed either in front as vajra fists or cradling the chin as the spine elongates and the eyes gaze to the sides into pure visions reflecting the innate activity of consciousness and perception. In the Nirmānakāya posture of the sage (rși) (see Figs 10 and 12), one squats with one's ankles together, knees pressed against the chest, and one's arms crossed in front, either with hands resting in the armpits or hugging the knees. The gaze is directed slightly downward through half-closed eyes to control the body's vital energies and bring the mind to stillness. As Pema Lingpa's text maintains, pristine awareness 'dwells like a lamp in a vase at the heart' of the physical body but only manifests as direct experience by maintaining the key points of posture, 'just as the limbs of a snake only become apparent when it is squeezed'.

The physical postures, suspended breath, and raised, lowered and sidelong gazes used in the Dzogchen practice of thod rgal serve as 'doors' to the direct experience of the multi-dimensionality of being beyond the single dualistic dimension to which human beings are habitually con-

This gaze correlates with śāmbhavimudrā in hațha yoga, which is said to synchronise the two hemispheres of the brain and lead directly to samādhi. See Birch 2011. strained. The indwelling pristine awareness that liberates consciousness is posited as the innermost essence of the heart (snying thig), and all methods of Dzogchen are directed towards making this a lived reality (see Fig. 11). The innate radiance (lhun gyis grub pa) of the heart-centre is held to manifest first as flickering and darting gossamer strands and later as spontaneously present spheres of light through a subtle channel that, like a white silken thread and 'far-ranging noose' connects the heart and eyes. The thig le, or subtle essences, appear in the empty mirror of the sky as reflections of innate reality and develop through four sequential visions. ${ }^{56}$ The halos of light ultimately divide and transform into five concentric circles, the central one symbolising pure unmanifest potentiality. As the circle widens through steady gaze, it eventually pervades immeasurable space as distinctions between subject and object, mind and body, vanish in the luminosity of enlightenment. ${ }^{57}$ As Pema Lingpa's revealed treasure text illustrated on the walls of the Lukhang proclaims:

Through the unmediated perception of reality, conceptual analysis naturally subsides... . Free of conflicting views, all things arise as intrinsic Luminosity... . As tainted aggregates dissolve, the body itself is naturally Enlightened (illuminated)!

$5^{6}$ The 'Four Visions' of thod rgal are described as the Direct Perception of the Ultimate Nature, the Vision of Increasing Experience, the Perfection of Intrinsic Awareness, and the Dissolution of [phenomena into] the Ultimate Nature. The visions are said to arise from the heart as reflections of the body's purified channels, energies and subtle essences. For further details, see Baker 2011 and Baker 2017.

57 This process echoes Matthew 6:22: 'Therefore when thy eye be single, thy whole body will be full of light'. 


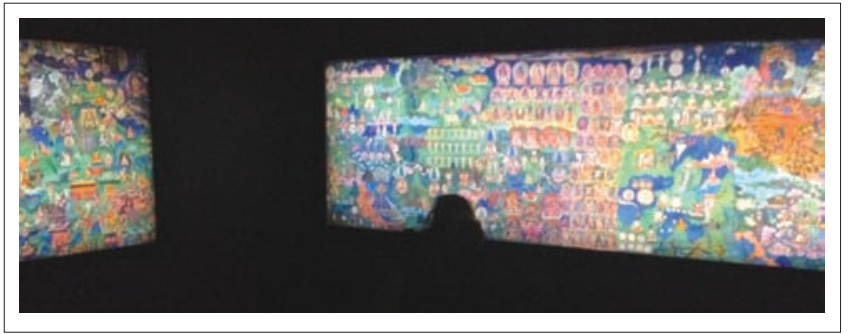

Figure 29.13 A 2015-16 exhibition at London's Wellcome Collection entitled 'Tibet's Secret Temple: Body, Mind and Meditation in Tantric Buddhism' featured life-sized facsimiles of the Lukhang murals, bringing to public view images that were once meant only for the eyes of Tibet's Dalai Lamas. Merging contemporary light technology with the murals' avant-garde depictions of human potential, the exhibition offered visitors both an educational and contemplative experience. ${ }^{\odot}$ Ian Baker

\section{Conclusion}

The Lukhang murals illustrating Rigdzin Pema Lingpa's treasure text 'Compendium of Enlightened Spontaneity' vividly reveal the essential role of the physical body in cultivating the integral states of awareness associated with Dzogchen, or Ati Yoga. From foundational practices that push body and mind to unaccustomed and instructive extremes to hațha yoga exercises for awakening the body's 'inner mandala' (nang pa'i dkyil 'khor) of subtle channels and vital energies, to the prescribed body postures for experiencing the visionary display of the body-mind's innermost essence (snying thig), Dzogchen is permeated by pro-somatic practices that lead to integrated, self-transcendent dimensions of being, held to represent the highest capacities of the human mind and body. Pema Lingpa's 'Secret Key', as illuminated on the walls of the Lukhang, offers an invaluable visual guide and inspiring artistic presentation of yogic practices formerly kept secret within initiatic lineages of Tibetan Buddhism. Transcending their historical context, the murals invite continued reflection on the intersection of physical and psychological disciplines in promoting human flourishing, and reveal the diverse ways that the human condition can be optimised through systematic physical cultivation concurrent with liberating reorientations of consciousness.

As visual culture, the Lukhang murals' fluent depictions of mind-body practices at the heart of the Tibetan Buddhist tradition reflect the words of Wassily Kandinsky, who wrote in 1911 in 'Concerning the Spiritual in Art' that:

Each period of culture produces an art of its own that can never be repeated... directed to the improvement and refinement of the human spirit. ${ }^{58}$

$5^{8} \quad$ See Kandinsky 1977, p. 15.
Analogously, Desi Sangye Gyatso, Tibet's visionary ruler at the turn of the 17th century who conceived of 'translating' Pema Lingpa's revealed treasure text into wall paintings in the private quarters of the Sixth Dalai Lama, achieved the 'unprecedented' by both preserving and interpreting an endangered body of cultural knowledge in artistic form. He simultaneously legitimised his choice of Tsangyang Gyatso as the Sixth Dalai Lama through a visual record of the transmission of teachings that Pema Lingpa revealed and to which Tsangyang Gyatso was ancestrally connected.

Beyond the cultural, doctrinal, and political concerns that contributed to their original production, the wall paintings in the Lukhang have been re-envisioned in the 21st century in ways that expand on the murals' innovative means of representing knowledge. In 2015, life-size digital facsimiles of the murals formed the core of an exhibition at London's Wellcome Collection entitled 'Tibet's Secret Temple: Body, Mind and Meditation in Tantric Buddhism' that transformed the murals' once highly esoteric subject matter into a public educational resource. Back-lit by panels of LED lights, the digitalised and illuminated facsimiles of the murals revealed not only an alternate vision of the human condition and its possibilities, as imagined in $17^{\text {th }}$ century Tibet, but the ways in which science, art, and technology can dynamically combine in the 21st century towards a renewed aesthetics of transcendent experience. The exhibition also consciously reflected on its own breaching of norms in popularising 'secret images' connected with a living esoteric tradition. This decision was guided by the published words of the current Fourteenth Dalai Lama who, in specific reference to the Lukhang murals, stated that 'the time of secrecy is over'.59

Beyond their original initiatory context, the images nonetheless maintained an analogous function in challenging unexamined habits of perception and, as religiously inspired art, inviting transcultural reflections on the sources of human meaning and wellbeing. What was gained and what was lost in moving the murals from the domain of the sacred to that of the resolutely secular is perhaps best understood within the Great Perfection's own internal commitment to reconciling false dichotomies. As Padmasambhava, the reputed source of the teachings that the murals illustrate, is said to have stated: 'Sampsāra and Nirvāna have no difference other than being unaware or aware' of the intrinsically undivided nature of reality.$^{60} \mathrm{In}$ other words, from the non-dual perspective of Dzogchen, enlightenment consists in recognising the unitary na-

See H.H. the Dalai Lama's 'Introduction' to The Dalai Lamas Se cret Temple: Tantric Wall Paintings from Tibet (Baker 2011).

6o See p. 414 above, for the full quotation. 
ture of all experience, beyond the dualising tendencies of thought and perception. It is surely such coalescent insight that inspired Desi Sangye Gyatso to envision and commission the Lukhang murals. It may also have been this view, applied too personally and out of context, that led to the Desi's beheading - a reminder that, as in its Western sense a century later, the movement towards perfection, or Enlightenment, however variously enacted, is not without hazard. ${ }^{61}$

\section{Appendix}

\section{'The Secret Key to the Channels and Winds' (Rtsa Rlung Gsang Ba'i Lde Mig)}

A Chapter from Pema Lingpa's Compendium of Enlightened Spontaneity (Rdzogs chen kun bzang dgongs'dus). ${ }^{62}$

Homage to Innate Enlightenment, Samantabhadra (kun tu bzang po)!63

I, the Powerful Skull-Garlanded Lotus (Rdo rje thod phreng rtsal) ${ }^{64}$ have composed this 'Secret Key' to elucidate the [nature of the] Inner Winds (rlung, Skt: prāna) to help practitioners to open their subtle channels, balance the three humours of wind, bile and phlegm, and bring wholeness to body and mind.

In an isolated place free from disturbances, abide in the non-conceptual space of 'leaping over the skull' (thod rgal) and generate boundless love and compassion for all beings. ${ }^{65}$

61 Enlightenment, in its Western sense, connotes the cultural ascendency of reason and intellect over faith and tradition. See $n$. 34 concerning the circumstances of Desi Sangye Gyato's murder.

$62 \quad$ KZGD, vol. 2, pp. 453-6o.

63 The primordial purity and self-liberated nature of human consciousness is symbolised in Dzogchen as the Buddha Samantabhadra, literally 'All Pervading Goodness'. The male polarity signifies supreme compassion while the female polarity represents all-encompassing wisdom.

64 A title of Padmasambhava, the 8th-century Buddhist master credited with having established Vajrayāna, or Tantric Buddhism in Tibet, and the reputed author of the 'Secret Key'.

65 Pema Lingpa presents the yogic exercises of channels and winds (rtsa rlung 'phrul 'khor) as preparations for the Dzogchen practices of ka dag khregs chod and lhun grub thod rgal, 'cutting through to primordial purity' and 'leaping over the skull', the latter of which relies upon subtle channels connecting the heart and eyes. Although khregs chod commonly precedes the practice of thod rgal, early Nyingma expositions of Nyingtik, or 'Heart Essence, often present thog rgal first. As with all practices of Vajrayāna Buddhism they are framed by the altruistic Mahāyāna intent to achieve enlightenment on behalf of all beings.

\section{The Yogic Movements [for Clearing Hindrances $]^{66}$}

First, expel the stale winds three times [from the two side channels]. ${ }^{67}$ Then rub the palms of your hands together and massage the left and right sides of the body.

Second, turn the feet outward and alternate turning them to the left and right.

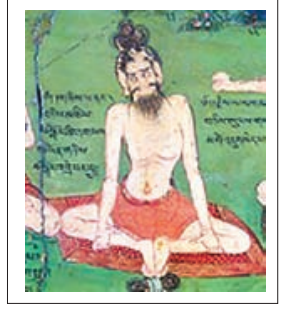

Third, apply [sesame] oil [to the body] and shake.

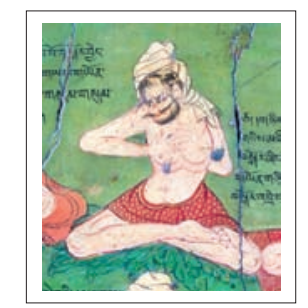

Fourth, churn the abdomen three times to the left and three times to the right. ${ }^{68}$

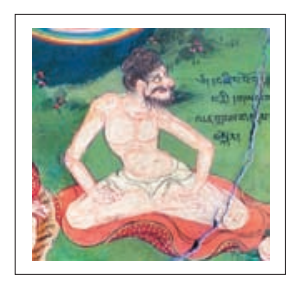

66 Pema Lingpa's text is illustrated below with relevant images from the paintings on the northern wall of the Lukhang temple. See Baker 2017 for a detailed history of 'magical movements' within the Tibetan Buddhist tradition. For a description of an elaborate system of 'phrul 'khor attributed to Vairocana, a contemporary of Padmasambhava, see Norbu 2008. See also Wangyal 2011 and publications by Chaoul-Reich for further explication of 'khrul 'khor within the Tibetan Bon tradition. The word 'magical' refers to the unusual psychological effects that the movements have on the mind.

67 Similar to methods of nādi shodana in hatha yoga, the stagnant winds are cleared through forceful exhalation through alternate nostrils while the other nostril is held closed with the thumb or ring finger. Emptying the two lateral channels concentrates energy and awareness in the body's central meridian.

68 Unlike uddiyāna bandha and nauli in hatha yoga, the abdomen is not pulled in towards the spine. 
Fifth, as if pushing a vajra, hold the breath [in the lower abdomen] and firmly press out both arms.

Sixth, like throwing a rock, fling the left and right arms outwards three times. ${ }^{69}$
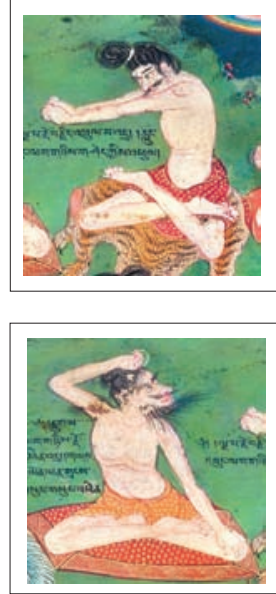

Seventh, rotate the wrists inwards and outwards three times each.
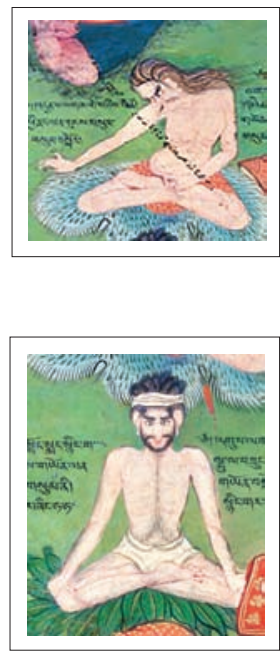

Eighth, while holding the breath [in the lower abdomen], rotate the entire body and the heart-centre three times to the left and right and exclaim $\mathrm{Ha} \mathrm{Ha}$.

Ninth, with hands [crossed in front and] holding the upper arms rotate to the left and right and then strike the heart-centre.

Tenth, while holding the breath [in the lower abdomen], rotate the left and right shoulders in and out three times each [with the arms straight and the fists pressing against the thighs].
Eleventh, strongly strike your fists nine times against your navel.

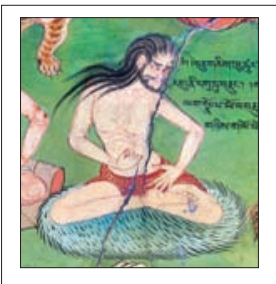

Twelfth, join the palms at the heart-centre and alternate striking your elbows against the sides of the ribs and then bang both [elbows against the body] simultaneously.

Thirteenth, interlacing your fingers, push back against the back of the neck and rotate [the head] three times to the left and three times to the right.

Fourteenth, like drawing a bow, pull three times to the left and three times to the right and, while crossing the arms, strike the point of the shoulder. $^{70}$
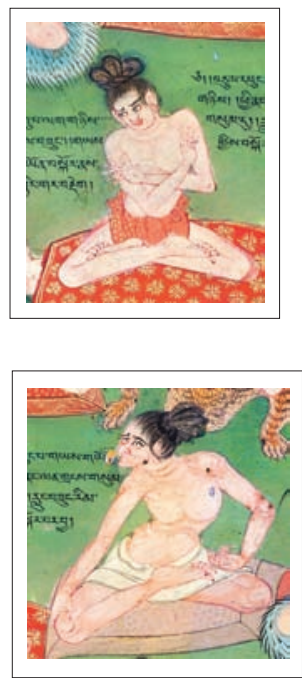

Fifteenth, rotate the head and eyes three times to the right and three times to the left. Then stretch the head nine times to the back and front, and nine times from side to side. Then shaking [the head] nine times, expel
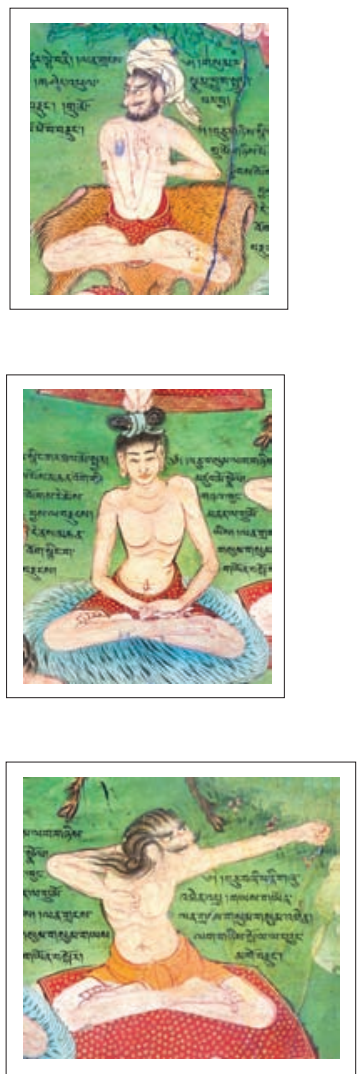
all stagnant air.

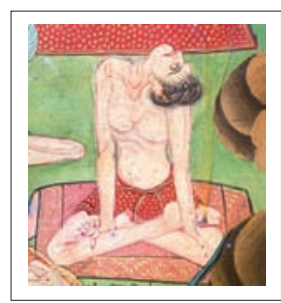

69 In traditional Chinese medicine this movement has the reputed benefit of opening the lung and heart meridians.
This movement is said to unblock and open the heart-centre, freeing it from stagnant 'wind' (rlung) and unproductive mental states. 
Sixteenth, the 'Lion's Frolic': Seal the eyes with the two index fingers, block the ears with the two thumbs, block the nostrils with the middle fingers and, with the small and ring fingers, seal the lips. ${ }^{71}$ Rotate the head three times to the left and three times to the right. Then shake [the upper body] three times [while exhaling].

Seventeenth, while standing up, shake the legs to the back and front and from left to right. Turn the arms to the left and right and shake them to the front.

Eighteenth, bend forward and touch the hands to the ground. Standing up, repeat nine times.

Nineteenth, while standing up strike the heels [on the ground] then, rising up, jump. Then alternate shaking the arms and legs. ${ }^{72}$

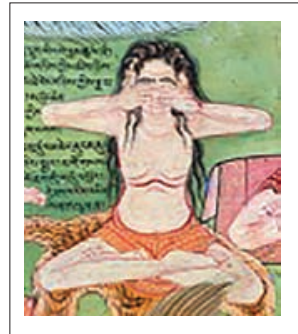

Twentieth, sit in [full lotus] vajra posture and lift up the body [with the hands pressing against the ground], then drop the body against the floor. Do this three times, shaking the body into wakefulness. ${ }^{73}$

Twenty-first, while lying back, hold the breath [in the lower abdomen] and lift your body up three times.
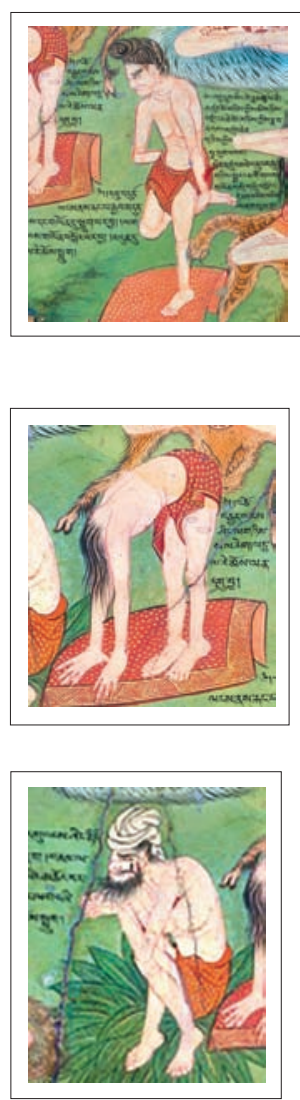

Twenty-third, sit comfortably in the seven-point posture of Vairocana. ${ }^{74}$

Twenty-second, bend forward and touch the forehead to the ground. Then rolling back, touch the toes to the ground. Shake the body and utter a strong Ha three times.
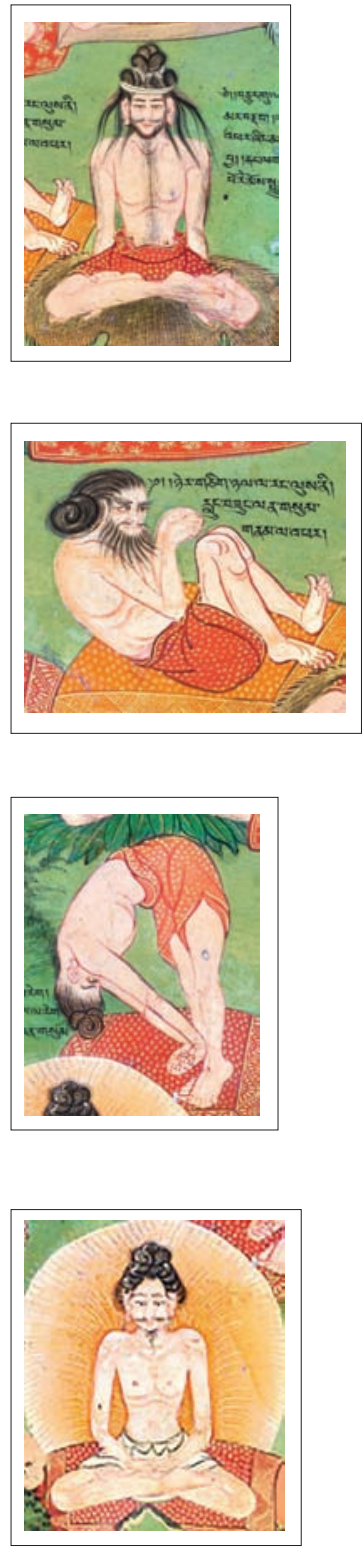

I, Pema [Padmasambhava], wrote down the [descriptions of these] 23 secret yogic movements. I pray to my heart son [Pema Lingpa] that they will benefit all beings.

This completes the first section, the stage of 'khrul 'khor [the yogic movements].

Samaya. Sealed! Sealed! Sealed!
This method of closing the doors to the senses is described in Patañjali's Yoga Sütras as pratyahara (so sor sdud pa), signifying the inward withdrawal of the senses towards progressively deeper states of unitary awareness. Following an alternate spelling, the exercise is sometimes alternatively translated as 'Lion's Liberation'.

This description appears to be shorthand for the controlled falls (bep) used in Yantra yoga ('khrul 'khor) to concentrate vital energy in the central channel and to stimulate the awakening of gtum mo, or 'fierce heat' (see Figs 9 and 14).
73 This is a version of mahāvedha, a hațha yoga exercise described in the corpus of 11th- to 12th-century texts entitled Amrtasiddhi, or 'Attainment of Immortality' ( $T:$ bDud rtsi grub $p a$ ). See Mallinson 2012 and Baker 2017.

74 The seven points consist of the legs in full lotus position, the spine erect, the shoulders broadened, the neck bent slightly forward, the hands in the gesture of equanimity (with the right hand resting on the left palm), the tip of the tongue touching the palate, and the gaze directed beyond the tip of the nose. 


\section{The Channels of the Human Body ${ }^{75}$}

In the crown chakra of great bliss

There are 360 channel petals;

In the throat chakra of gathering taste

There are 16 channel petals;

In the heart-centre, the dharma chakra

There are eight channel petals;

In the navel chakra of emanation;

There are 64 channel petals;

In the secret centre, the chakra of preserving bliss ${ }^{76}$

There are 28 channel petals.

The entire body contains 21,00o channel petals.

The three principal channels are:

The uma, roma, and kyangma.77

The presentation of the subtle energy channels ( $r t s a$, Skt: $n \bar{a} d i)$ in Tibetan Buddhism derives from Indian sources and varies in its enumeration of the number and location of specific channels and energy plexuses ('khorlo, Skt: cakra). The Tantras and Tibetan medical systems generally describe 72 ,0oo such channels within the human body that allow for the flow of awareness throughout the physical organism. The hollow, tubular ducts are described as symbolising the unlimited space through which consciousness can express itself, with the thig le, or psychophysical essences, representing the base for all appearance and manifestation. Pema Lingpa's overview of the subtle body focuses on three principal energy channels that parallel the spine and which, along with five associated energy plexuses (cakra), form the basis for the completion stage practices of Anu Yoga (rjes su rnal'byor) (see Figs 11 and 15).

This refers to the root cakra in the genital region that serves as a reservoir of bliss so long as the relative thig le, or sexual fluids, are retained and not lost through ejaculation, especially within the context of dual-cultivation with a consort (las kyi phyag rgya, Skt: karmamudrā).

The three fundamental channels rtsa dbu ma, ro ma, and rkyang ma differ in fundamental ways from the sushumna, ida, and pingala nādi described in hațha yoga (see Figs 11 and 15). In the Dzogchen view of embryology, the navel cakra develops first, followed by the crown cakra as a result of a connecting life-channel' (srog rtsa) that further differentiates into the spinal cord and spine, yet remains as the unifying energy of the rtsa dbu ma (Skt: avadhūti) central meridian at the core of tantric yoga. Four finger-widths below the navel, the dbuma intersects with two ascending lateral channels called ro ma and rkyang ma. The ro $m a$ is visualised as white in colour and as corresponding to lunar energy. It is said to lie on the right side of the body in men and on the left side in women. Ro, in Tibetan, means 'flavour', and the principal function of the ro $m a$ is to provide the sensation of pleasure. The ro $m a$ is thus further correlated with the tantric principle of thabs lam, or method. The rkyang ma is connected with the principle of ' $\mathrm{grol}$ lam, or liberation and is visualised as red and as corresponding to solar energy. It lies on the left side of the body in men and on the right side in women. Rkyang means 'sole', and unlike the ro ma, the rkyang ma is not connected with any secondary channels. Control of the energies that flow through the rkyang ma is considered fundamental for develop-
Their inner space is erect like pillars.

Their upper ends appear like the horns of the bamen ['wild ox']. Their lower ends are curved like the Tibetan letter cha.

Uma, the channel of the wisdom flow,

Has three different names: ${ }^{78}$

Outwardly it is known as Uma [the 'central'], inwardly as Kundarma [the 'all-encompassing'], and secretly as Shel Bugchen, [the 'great crystalline tube']. ${ }^{79}$

It is empty and transparent and free of blood and fluids. Along its length are four principal channel wheels [cakra] through which Awareness Wisdom (rig pa'i ye she) ${ }^{80}$ flows unimpeded. Primordial Awareness (rig pa) is supported, in turn, by a luminous energy sphere [located at the heart cakra]. The 21,0oo channel petals [of the subtle body] connect to 21,00o internal winds that differentiate the pure and impure essences (thig le) of the body.

This completes the section on the subtle channels $(r t s a)$ of the physical body.

Samaya. Sealed! Sealed! Sealed!

\section{Igniting Blissful Heat to Enhance Awareness ${ }^{81}$}

Expel the stale airs three times [from each nostril] and inhale in an instant the essence of the wisdom präna from the tip of

ing insight into emptiness as the energetic basis for all manifestation. The goal of all practices connected to the channels and winds (rtsa rlung) can be generalised as the unification of the energies of the body's two lateral channels into the wisdom flow of the central meridian (rtsa dbu ma) that runs from the base of the spine to the crown of the head, an energetic current possibly related in human anatomy to the prenatal notochord.

78 The three principle channels further correlate with Dzogchen's presentation of the triune reality of the ground of being (kun gzhi). The Essence or Pure Potentiality (ngo stong pa) relates to the avadhüti itself, the Luminous Nature (rang bzhin gsal ba) to the ro $m a$, and the unceasing Energy of Manifestation (thugs rje kun khyab) to the rkyang ma.

79 This microscopic and translucent channel is described in Dzogchen as originating in the innermost centre of the heart cakra and rising up through the central channel into the brain where it bifurcates and arcs forward to terminate at the centre of the pupils of both eyes. In distinction to the channels that circulate prāna, or vital energy, the crystalline kati channel is described in oral tradition as a 'light channel' that connects the Clear Light wisdom located in the heart cakra with the Clear Light awareness 'seated' in the brain. As with all practices of Dzogchen, it remains 'secret' until manifested through direct experience.

$80 \quad$ The Tibetan word rig pa generally means 'awareness' or 'knowledge'. In Dzogchen, it further refers to abiding in the mind's essential nature as distinct from ordinary mental processes. The word ye shes generally translates as 'primordial wisdom' and is an intrinsic feature of enlightened consciousness.

81 This section describes the technique of gtum mo, literally 'fierce female energy', which corresponds with the Indian system of 
the nose and swallow the saliva. Pull up the lower winds [by gently contracting the pelvic floor] and [while pressing down with the upper winds] hold the energy at the navel centre [by applying the 'Vase Breath' (bum chen, Skt: kumbhaka]. Then gradually perform the 'khrul'khor [the 23 yogic movements].

[Again] expel the stale winds three times [from the side channels]. Then gently unite the lower and upper winds [at a point four finger widths below the navel] by applying jam rlung [exhaling and inhaling softly and completely with a gentle breath retention]. Next, visualise the central channel (rtsa dbuma) as ascending from the secret centre [genitals] to the crown [of the head], empty and unimpeded, the size of a bamboo arrow, bluish white and free of blood, lymph, or any fluids. ${ }^{82}$ At the navel cakra, within the central channel, is a red four-petalled lotus. In its centre is the syllable Yam and, on top of it, a red Ram. ${ }^{83}$ Wind stirs from the Yam and strikes the Ram, igniting a fire that rises [within the central channel]. When the flame touches the white [inverted] Ham at the crown cakra, it causes the red and white essences (thig le) to descend. When they reach the Ram at the navel cakra the inner fire blazes and incinerates all habitual [and limiting] tendencies [of the mind]. While meditating on the expanding bliss, imagine that you are receiving the third empowerment ${ }^{84}$ that [activates the channels and winds and] awakens the innate heat and wisdom [of the umbilical centre].

canḍāầ or kuṇdalinī yoga. In the context of Vajrayāna Buddhism the incandescent bliss that rises through the practice is not an end in itself but 'expedient means' (thabs lam, Skt: upāya) for recognising the true nature of the mind and thus achieving liberation from conditioned states, including attachment to bliss itself. All physical methods in Dzogchen can be divided into either bogs dun or bgegs sel, practices that either enhance the realisation of non-dual wakefulness (such as gtum mo) or dispel hindrances (such as 'khrul'khor).

82 See n. 78 for discussion of the role of the central channel in tantra and Dzogchen. For the practice of gtum mo there are two main bodily positions. In the first, the practitioner sits crosslegged with the arms held along the sides of the body with the hands turned upward and, with thumbs connected to the roots of the ring fingers, pressed against the insides of the thighs as 'vajra fists'. In the second position, one sits with the legs raised in front with arms crossed and the elbows resting on the tops of the knees to simulate a 'stove', often supported by a meditation belt.

$83 \quad$ Yam and Ram are seed-syllables (yi ge) signifying air and fire. Ham, visualised in Pema Lingpa's presentation of gtum mo as located at the crown of the head, represents water, or the dimension of fluidity. In other contexts, this practice is also performed by visualising a short blazing $A h$ four finger-widths' beneath the navel that, in turn, causes the 'white element' at the crown of the head to melt and drip down through the central channel.

84 Vajrayāna practice is normally connected to receiving four successive tantric empowerments (dbang bzhi) that prepare the mind and body for the experiences that arise through the practices of the Inner Tantras. The third empowerment of 'knowledge-wisdom' (shes rab ye shes kyi dbang) authorises the practitioner to meditate on the union of bliss and emptiness aroused by the Anu Yoga practices of gtum mo, rtsa rlung, and
This completes the third section of meditating on Fierce Heat (gtum mo) in the evening. ${ }^{85}$

Samaya. Sealed! Sealed! Sealed!

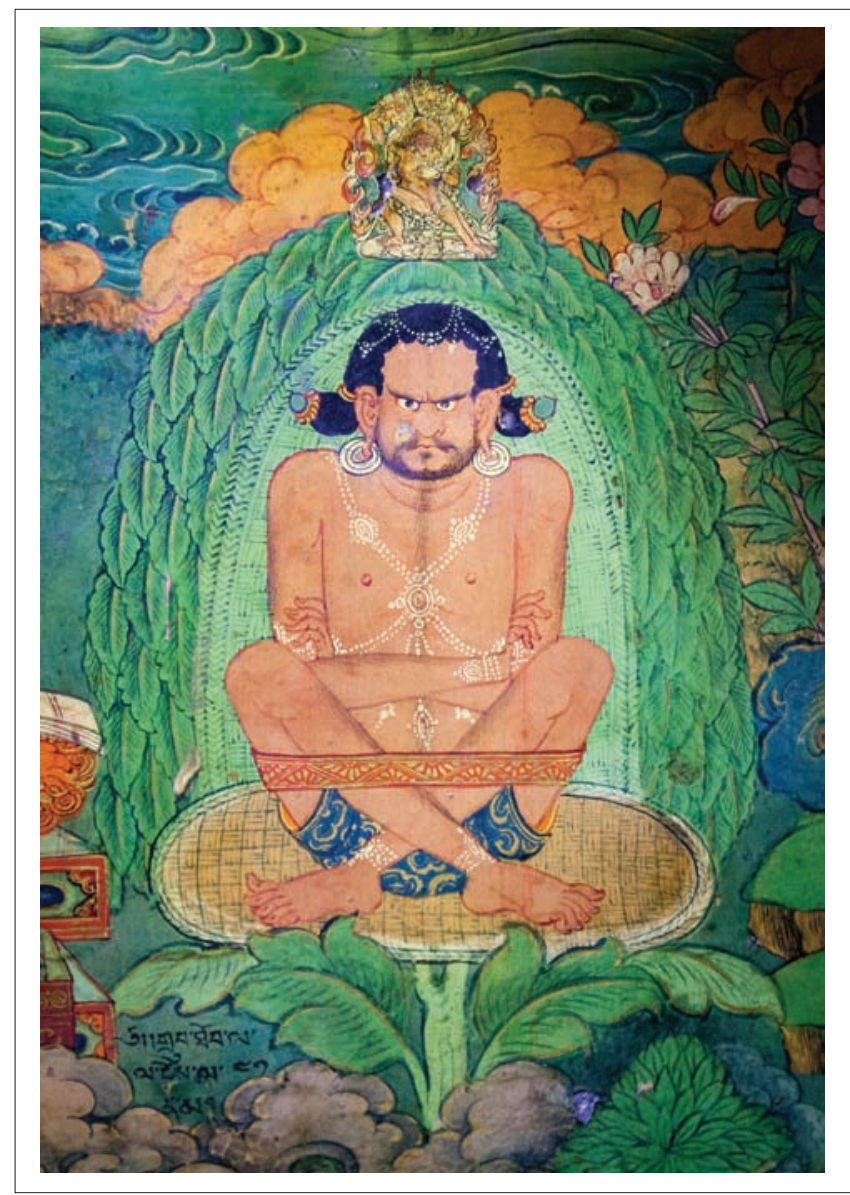

Figure 29.14 A mahāsiddha, or realised adept, pictured on the Lukhang murals sits in a posture associated with the practice of Fierce Heat (gtum mo), as described in Pema Lingpa's revealed treatise, 'Secret Key to the Channels and Winds'. 이 Ian Baker

\section{Entering Consciousness into the Vase at Night $^{86}$}

[For the practice of sleep] lie on your right side and meditate that the central channel (dbuma) is the size of an arrow and empty and transparent and free of blood and fluids. Primordial Awareness (rig pa) abides as a white $\mathrm{Hum}^{87}$ at

\section{karmamudrā.}

85 When gtum mo is combined with other Anu Yoga practices, it is conventionally performed in the evening; otherwise it may be practised at any time of day or night.

86 'Vase' refers, in this context, to the containing of the senses as one falls asleep. The vase into which the sensory functions are withdrawn can refer to either the heart cakra or the navel cakra.

87 The seed-syllable Hum refers in Vajrayāna Buddhism to the innate wisdom mind while, in Dzogchen, the seed-syllable $A h$ represents the mind's primordial nature (Logos). While the syllable Hum is illustrated on the western mural in the context of 
the navel cakra, in the centre of a four-petalled lotus. The Hum is unmoving, clear, and brilliant. Contemplate that all the coarse and subtle thoughts that ride on the vehicle of the breath dissolve into the upward-facing Hum. When thoughts arise, concentrate on the Hum at the navel cakra.

Following this, at the point of sleep, imagine your Primordial Awareness as a radiant white Hum blossoming in your heart cakra at the centre of a four-petalled lotus. Meditate that all thoughts [and sensations] dissolve into this luminous Hum. Join the lower and upper winds at your heart cakra. The Hum shines within the heart like a lamp inside a vase. Meditate on clarity and emptiness free of grasping and your sleep will naturally arise as unobstructed Luminosity. Meditate in this way again and again and the movement of outer and inner thoughts will dissolve into [all-pervasive] Clear Light. This completes the fourth section of entering the objects of consciousness into the vase.

Samaya. Sealed! Sealed! Sealed!

\section{Resting Awareness in its Natural State in the Early Morning}

At the moment of waking, sit in the rși posture ${ }^{88}$ and expel the stale winds three times [from both nostrils]. Then, release the two winds [that were joined] at your heart-centre and [while shouting $\mathrm{Ha}$ into the sky] project the Hum through the crown of your head to a bow's length above and in front. Focus your Awareness and internal energy (rlung, Skt: prāna) on the Hum [in the sky above you] while holding a gentle 'vase breath'. ${ }^{89}$ Meditate undistractedly in a state of naturalness, giving rise to non-conceptual wisdom. Allow the Hum to naturally dissolve [into infinite space] and remain free of all conceptual activity.

When the sun is shining focus [your attention] on [the naturally arising visions of ] thod rgal. ${ }^{90}$

the preliminary Dzogchen practices, $A h$ is pictured far more frequently and often substitutes for instances in which Pema Lingpa's text specifies the visualisation of a Hum. In any case, the practice described here, 'Retaining Wakefulness in the Vase', is often done while visualising an $A h$ at the centre of the heart which lights up the interior of the body and radiates beyond it, leading to 'capturing Luminosity during deep sleep'.

88 One of three positions emphasised for the practice of thod rgal, the rși posture consists of sitting with an erect spine with the legs pulled up in front and the arms either around or resting on top of the knees. This practice is also commonly done while crouched in the 'lion's posture' (see Figs 10 and 12).

89 In the practice of thod rgal, breathing occurs almost imperceptibly through the mouth without any manipulation of the prāna. The out-breath is naturally longer with a gentle holding of the empty breath before inhaling. In Anu Yoga, prāna is controlled so as to control the mind. In Ati Yoga (Dzogchen) the mind is controlled so as to bring prāna naturally into balance. field entoptic phenomena identified in 1924 by the German ophthalmologist Richard Scheerer and described as the appearance

Spend your days and nights united with ultimate reality.

An instruction of this type cannot be found [elsewhere] in Tibet or India.

This sacred heart blood of me, Pema [Padmasambhava], may it meet with my destined heart son [Pema Lingpa].

Samaya, Sealed! Sealed! Sealed!

The light rays of Orgyen Pema's [Padmasambhava's] compassion

Opened the lotus heart of me, Pema [Lingpa and revealed]

The supreme path for accomplishing stainless Buddha [Nature].

For the benefit of qualified practitioners

The light rays of the white conch scrolls shone forth,

And were written down from the yellow parchment [shog gser].

May these teachings spread throughout the world!

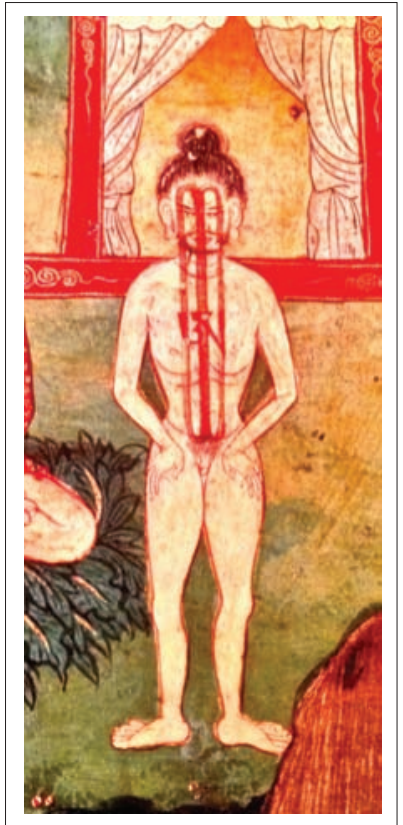

Figure 29.15 This detail from the Lukhang murals shows the three principal energy channels cultivated in Tibetan yoga. The syllable $A h$ at the figure's heart centre signifies the state of primordial awareness (rig pa. Skt. vidya). ${ }^{\odot}$ Ian Baker

of bright dots flowing along wave-like lines in the visual field when looking into bright blue light, such as the sky. Ophthalmologically, the dots appear as a result of leukocytes, or white blood cells, flowing through the macular, retinal capillaries of the eyes in synchrony with the cardiac cycle between the beginning of one heartbeat and the onset of the next. In a convergence of science and traditional accounts, the luminous orbs that appear before one's eyes are manifestations of the cellular structure of one's own blood, or heart essence (nying thig). The blue field entoptic phenomena are distinct from other entoptic phenomena such as 'floaters' (muscae volitantes) which result from debris floating on the eye's vitreous humour. In the context of thod rgal, subjective entoptic phenomena and associated hypnogogic imagery serve as affective entry points into liberative non-dual states of consciousness. 


\section{Bibliography}

\section{Primary Sources}

Ngag dbang blo bzang rgya mtsho'irnam thar'phro 'thus (Autobiography of the Fifth Dalai Lama Ngawang Lobzang Gyatso, 1617-82). Completed by Desi Sangge Gyatso. 3 vols. Block print. 'Bras spung, Lhasa. Dga' ldan pho brang. Available at твRC W8239.

Padma gling pa, Rdzogs chen kun bzang dgongs'dus, in 'The Rediscovered Teachings of the Great Padma-glin-pa', 21 vols. Thimphu: Kunsang Tobgay 1975-76. Also available at твRC (resource ID T1851).

gSang ba'irnam thar rgya can (A Record of the Visionary Experiences of the Fifth Dalai Lama Ngag dban blo bzang rgya mtsho, Sman rtsis Shesrig Spendzod, vol. 42), Leh 1972.

Sde srid gSangs rgyas rgya mtsho, Dr'in can rtsa ba'i bla ma ngag dbang blo bzang rgya mtsho'i thun mong phyi'i rnam thar du kula'igas bzang glegs bam gsum pa'i 'phros, vols IV-VI, Zhol edn.

- Thams cad mkhyen pa drug pa blo bzang rin chen tshangs dbyangs rgya mtsho'i thun mong phyi'i rnam par thar pa du kü la'i 'phro'thud rab gsal gser gyi snye ma. Block print. 'Bras spungs, Lhasa: Dga' ldan pho brang. Available at твRC $\mathrm{W}_{2} \mathrm{CZ}_{7} 844$.

Ngag dbang blo bzang rgya mtsho'i rnam thar 'phro 'thus, 3 vols. Block print. 'Bras spung, Lhasa. Dga'ldan pho brang. Available at TBRC W8239.

1973. Bai dūr snon po: Being the text of Gso ba rig pa'i bstan bcos sman bla'i gsal byed bai dur sngon po'i ma Iii ka. 4 vols. From a Lcags po ri block print carved 1888-92. Leh: T.Y. Tashigangpa.

1994. gSo ba rig pa'ibstan bcos sman bla'idgongs rgyan rgyud bzhi'i gsal byed bai dūr ya sngon po'i malli ka, 2 vols., Dharamsala: Bod gzhung sman rtsis khang.

\section{Secondary Sources}

Aris, M. 1979, Bhutan: The Early History of a Himalayan Kingdom, Warminster: Aris \& Phillips.

1980, 'Analysis of the biographies of Padmasambhava according to Tibetan tradition', in Aris and Aung San Suu Kyi (eds) $45^{-52}$.

1988, Hidden Treasures and Secret Lives: A Study of Pemalingpa (1450-1521) and the Sixth Dalai Lama (1683-1706), Delhi: Motilal Banarsidass.

Aris M. and Aung San Suu Kyi (eds), 1980, Tibetan Studies in Honour of Hugh Richardson, Warminster: Aris \& Phillips.

Baker, I. 1997, The Tibetan Art of Healing, London: Thames \& Hudson. 2017, 'Tibetan yoga: somatic practice in Vajrayāna and Dzogchen', in Maas et al. (eds).

- Forthcoming 2018, Tibetan Yoga: Secrets from the Source, London: Thames \& Hudson.

Baker, I. and T. Laird 2011 [200o], The Dalai Lama's Secret Temple: Tantric Wall Paintings from Tibet, London: Thames \& Hudson.

Birch, J. 2011, 'The Meaning of Hatha in Early Hathayoga', Journal of American Oriental Studies 131.4, 527-54.

Blezer H. et al. (eds) 2002, Religion and Secular Culture in Tibet: Tibetan Studies II: Proceedings of the Ninth Seminar of the International Association of Tibetan Studies, Leiden 200o, Leiden: Brill.

Cabezón J. and Jackson R. (eds) 1996, Tibetan Literature: Studies in Genre, Ithaca, NY: Snow Lion Publications.

Chagme, K. (tr. B.A. Wallace) 2000, Naked Awareness: Practical Instructions on the Union of Mahamudra and Dzogchen, Ithaca NY: Snow Lion Publications.

Chaoul-Reich, A. 2006, 'Magical movements ('phrul'khor): ancient yogic practices in the Bon Religion and contemporary medical perspectives', PHD diss., Houston: Rice University.

Dargyay, E. 1977, The Rise of Esoteric Buddhism in Tibet, Delhi: Motilal Banarsidass.

Davidson R. and Goodman S. (eds) 1992, Tibetan Buddhism: Reason and Revelation, Albany: State University of New York Press.

Dorji, C.T. 1995, A Political and Religious History of Bhutan, Delhi: Prominent Publishers.

Douglas, K., and G. Bays (tr.) 1978, The Life and Liberation of Padmasambhava, 2 vols, Berkeley: Dharma Publishing.

Dowman, K. (tr.) 1984, Sky Dancer, London: Routledge and Kegan Paul.

Dudjom Rinpoche, J.Y.D. (tr. Gyurme Dorje and M. Kapstein), 1991, The Nyingma School of Tibetan Buddhism: Its Fundamentals and History, 2 vols, Boston: Wisdom Publications.

Evans-Wentz, W.Y. (ed.) 1954, The Tibetan Book of the Great Liberation, London: OuP.

Gangteng, Literary Committee (2008), The Rosary ofJewels: Biographies of the Successive Throne Holders of Gangteng, Bhutan: Gangteng Monastery.

Guenther, H. 1987, The Symbolic Recreation of the World According to the Tibetan Buddhist Tradition of Tantric Visualisation Otherwise Known as The Developing Phase, Lotsawa House.

Gyatso, J. 1992, 'Genre, authorship, and transmission in visionary Buddhism: the literary traditions of Thang-stong rGyal-po', in Davidson and Goodman (eds), 95-106.

- 1996, 'Drawn from the Tibetan treasury: the gTer ma Literature', in Cabezón and Jackson (eds), 147-69.

1998. Apparitions of the Self: The Secret Autobiographies of a Tibetan Visionary. Princeton: Princeton University Press.

2012, 'Looking for gender in the medical paintings of Desi Sangye Gyatso, Regent of the Tibetan Buddhist state', Asian Medicine: Tradition and Modernity 6, 217-92.

2014. 'Buddhist Practice and Ideals in Desi Sangye Gyatso's Medical Paintings', in Hofer (ed.), 198-220.

2015, Being Human in a Buddhist World: An Intellectual History of Medicine in Early Modern Tibet, New York: Columbia University Press.

Dorje G. 1994, Total Illumination of the Essence: The Teaching Manual for The Union of Samantabhadra's Intentions, Boulder, co: Yeshe Korlo Publications.

Harding, S. 2003, The Life and Revelations of Pema Lingpa, Ithaca, NY: Snow Lion Publications.

Hofer T. (ed.) 2014, Bodies in Balance: The Art of Tibetan Medicine, Seattle: University of Washington Press.

Kapstein, M. 1989, 'The Purificatory Gem and its cleansing: a late Tibetan polemical discussion of apocryphal texts', History of Religions 28(3), 217-44.

2000, The Tibetan Assimilation of Buddhism: Conversion, Contestation, and Memory, Oxford: oup.

2006, The Tibetans, Oxford: Blackwell Publishing.

Kandinsky, W. 1977, Concerning the Spiritual in Art, New York: Dover Publications.

Karmay, S. 1988, Secret Visions of the Fifth Dalai Lama. The Gold Manuscript in the Fournier Collection, London: Serindia Publications.

Kongtrul, J. (tr. E. Guarisco and I. McLeod) 2005, The Treasury of Knowledge, Book Six, Part Four: Systems of Buddhist Tantra, , Ithaca, NY: Snow Lion Publications.

Kvaerne, P. 1990, 'Review of Hidden Treasures and Secret Lives', Acta Orientalia 51, 302-6.

Lipman, K. 1987, 'The dynamic yoga of Tibet: combining asanas, breathing exercises, and flowing movements, Yantra Yoga aims to return us to our "natural state"', cited in Yoga Journal, May 1987, no. 74, Active Interest Media. ISSN 0191-0965. 
Luczantis, C. 2011, 'Locating Great Perfection: the murals of the Lhasa Lukhang', Orientations 42(2), 102-11.

Maas P. et al. (eds) 2017, Yoga in Transformation: Historical and Contemporary Perspectives on a Global Phenomenon. Vienna: Vienna University Press.

Mallinson, J. and M. Singleton. 2017, The Roots of Yoga: A Sourcebook from the Indic Traditions, London: Penguin Classics.

Mayer, R. 1992, 'Review of Hidden Treasures and Secret Lives', Religion $22(2), 187$.

Meyer, F. 1992. 'Introduction: the medical paintings of Tibet', in Parfionovitch, Dorje and Meyer (eds), 2-13.

Mullin, G. 2006, The Practice of the Six Yogas of Naropa: Tsongkhapa's Commentary, Ithaca, NY: Snow Lion Publications.

Namdak, T. and R. Dixey 2002, Heart Drops of Dharmakaya, Boston: Wisdom Publications.

Namdak, T. and J. Myrdhin Reynolds 20o6, Bonpo Dzogchen Teachings, Boston: Wisdom Publications.

Norbu, N. (tr. A. Clemente) 20o8, Yantra Yoga: The Tibetan Yoga of Movement, Ithaca, NY: Snow Lion Publications.

Odier, D. 2005, Yoga Spandakarika: The Sacred Texts at the Origin of Tantra, Rochester, VT: Inner Traditions.

Parfionovitch, Y., G. Dorje and F. Meyer (eds) 1992, Tibetan Medical Paintings: Illustrations to the Blue Beryl Treatise of Sangye Gyamtso (1653-1705), 2 vols, New York: Abrams.

Robinson, J. 1996, 'The lives of Indian Buddhist saints: biography, hagiography and myth', in Cabezón and Jackson (eds), 57-69.

Rossi D. and C. Oliphant of Rossie (eds) 2016, Sharro - Festschrift for Chögyal Namkhai Norbu. Rudolfstetten: Garuda Verlag:

Samuel, G. 1993, Civilized Shamans: Buddhism in Tibetan Societies, Washington, DC: Smithsonian Institution Press.

2008, Origins of Yoga and Tantra: Indic Religions to the Thirteenth Century, Cambridge: cup.
Singh, J. 1979, Siva Sūtras: The Yoga of Supreme Identity, Delhi: Motilal Benarsidas.

Singleton, M. 2010, Yoga Body: The Origins of Modern Postural Practice, Oxford: OUP.

Snellgrove, D. 1987, Indo-Tibetan Buddhism:Indian Buddhists and their Tibetan Successors, Boston: Shambhala Publications.

Thondup, T. 1986, Hidden Teachings of Tibet: An Explanation of the Terma Tradition of Tibetan Buddhism, Boston: Wisdom Publications. 1990, 'The Terma Tradition of the Nyingmapa School', Tibet Journal 15(4), 149-58.

Thurman, R. 1991, 'Review of Hidden Treasures and Secret Lives', The Journal of Asian Studies 5o(2), 375-7.

Tshewang, P. 1995, 'The Biography of Pemalingpa', in Tshewang et al., 23-98.

Tshewang, P., K. Phuntshok Tashi, C. Butters and S. Saetreng 1995, The Treasure Revealer of Bhutan: Pemalingpa, the Terma Tradition and Its Critics, Bibliotheca Himalayica, series III, vol. 8, Kathmandu, Nepal: EMr Publishing House.

Van Schaik, S.J. 2004, Approaching the Great Perfection: Simultaneous and Gradual Approaches to Dzogchen Practice in the Longchen Nyingtig, Boston: Wisdom Publications.

2004b, 'The Early Days of the Great Perfection', Journal of the International Association of Buddhist Studies 27(1):165-206.

Wangyal, T. 2011, Awakening the Sacred Body: Tibetan Yogas of Breath and Movement, London: Hay House, Inc.

Winkler, J. 2002, 'The rDzogs Chen Murals of the Lhasa Klu-Khang', in Blezer et al. (eds), 321-43.

2016. 'The Literary Sources of the Klu-Khang Murals', in Rossi and Oliphant of Rossie (eds), 319-39.

Yeshe, L.T. 1998, The Bliss of Inner Fire: Heart Practice of the Six Yogas of Naropa, Boston: Wisdom Publications.

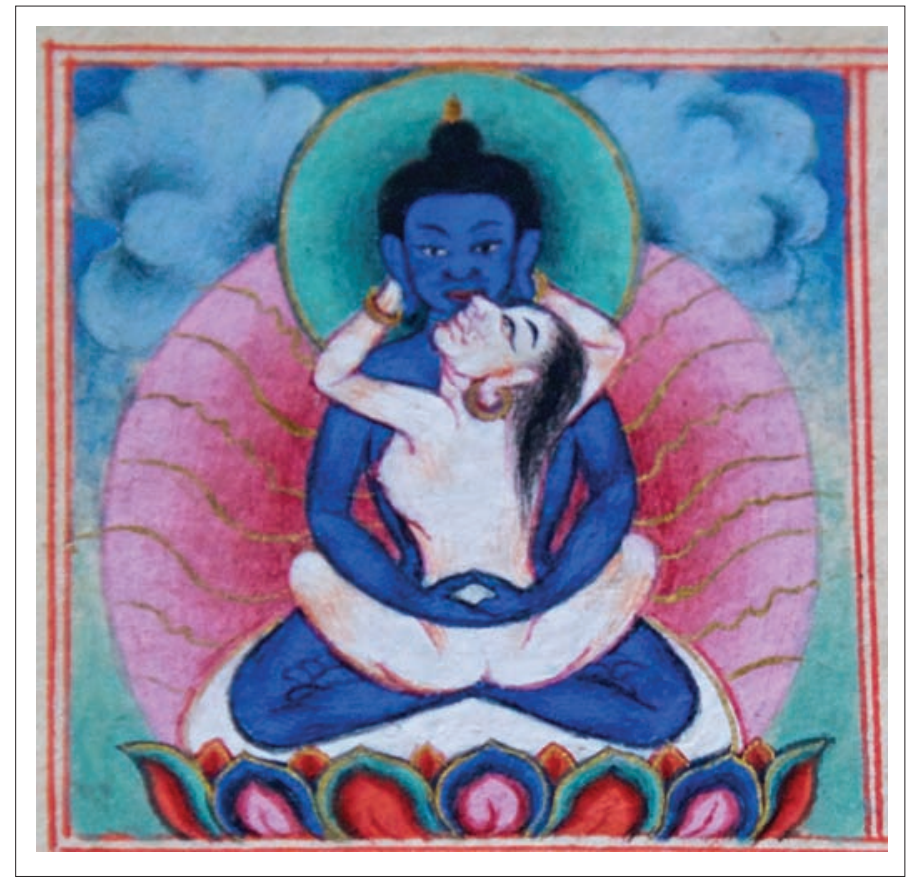

Figure 29.16 This image of Buddha Samantabhadra, 'All Pervading Goodness', appears on the cover folio of vol. 1 of a two-volume 17th-century copy of Pema Lingpa's 'Compendium of Enlightened Spontaneity' that served as a source text for the Lukhang murals. The original manuscript is kept at Gangtey Monastery in Bhutan (see also note 13). $\odot$ Ian Baker 